\title{
EL POLÍGRAFO Y SU UTILIZACIÓN COMO ACTO DE INVESTIGACIÓN EN EL DERECHO SANCIONATORIO
}

\author{
Carlos Arturo Gómez Pavajeau* \\ Francisco Javier Farfán Molina**
}

\begin{abstract}
Resumen: El polígrafo o detector de mentiras es una técnica auxiliar para la averiguación de la verdad, que le otorga al juez criterios para corroborar la veracidad o la credibilidad de un testimonio o la versión del investigado. Pese a que la jurisprudencia de la Sala Penal de la Corte Suprema de Justicia considera que el polígrafo no es un método admisible para la investigación de los delitos, en el presente escrito se realiza un estudio orientado a demostrar que el uso del polígrafo encuentra respaldo o asidero jurídico en los estándares convencionales de derechos humanos, en el principio de la libertad de prueba, y en el texto de la Ley Estatutaria de Inteligencia y Contrainteligencia, que permite su utilización como medio probatorio para desvincular con
\end{abstract}

* Profesor Titular de Derecho Penal y Disciplinario de la Universidad Externado de Colombia. Cofundador y Consejero Académico del Instituto Colombiano de Derecho Disciplinario y de la Confederación Internacional de Derecho Disciplinario. Coordinador Académico de Barras de la Defensoría del Pueblo y Consultor de la Escuela Judicial "Rodrigo Lara Bonilla". E-mail: gomezpavajeau@ hotmail.com

** Ex Procurador Delegado ante la Sala Penal de la Corte Suprema de Justicia. Profesor de la Universidad Externado de Colombia. Abogado Consultor. E-mail: ffarfanmolina@hotmail.com. Fecha de recepción: 30 de marzo de 2014. Fecha de modificación: 20 de junio de 2014. Fecha de aprobación: 2 de julio de 2014. Para citar el artículo: CARlos Arturo Gómez PavajeAu, Francisco Javier FarFÁN MOLINA. "El polígrafo y su utilización como acto de investigación en el derecho sancionatorio", Revista Derecho Penal y Criminología, Vol. 35, n. 98, enero-junio de 2014, Bogotá, Universidad Externado de Colombia, 2014, pp. 131-179. 
justa causa a los empleados que no superen las pruebas de confiabilidad y credibilidad para el acceso o la prestación de servicios en los organismos de inteligencia del Estado.

Palabras clave: Polígrafo; Dignidad humana; Prueba ilícita; Control de convencionalidad; Consentimiento informado; Libertad de prueba; Valoración del testimonio; Asesores especializados; Prueba novel; Pruebas de credibilidad y confiabilidad.

\title{
THE POLYGRAPH AND THEIR USE AS ACT OF RESEARCH IN TORT LAW
}

\begin{abstract}
The polygraph or lie detector is an auxiliary technique for the determination of the truth, which gives the judge criteria to corroborate the veracity or credibility of a witness or the version of the investigation. Although the jurisprudence of the Criminal Chamber of the Supreme Court of Justice ruled that the polygraph is not a permissible method for the ascertainment of truth, this article offers a to demonstrate that the use of polygraph for investigating crimes, legally relies on conventional standards of human rights, the principle of freedom of evidence, and the text of the statute law of intelligence and counterintelligence, which allows its use as evidence to decouple just cause employees to not pass the tests of reliability and credibility for access to or the provision of services in state intelligence agencies.

Keywords: Polygraph; Human Dignity; Illegal Evidence; Control of Compliance; Informed Consent; Free Test; Evaluation of Witness; Specialist Consultants; Novel Test; Tests of Credibility and Reliability.
\end{abstract}

\section{INTRODUCCIÓN}

La técnica y los descubrimientos científicos han aportado al mundo de la justicia instrumentos y herramientas que, debidamente evaluadas, contribuyen a la completa averiguación de la verdad de los hechos punibles y sus autores.

El polígrafo o detector de mentiras es,

[...] un aparato capaz de registrar los cambios físico-síquicos de una persona, cuando es interrogada mediante un "test de verdad", sobre un hecho en el que se sospecha ha participado o del cual tiene conocimiento como testigo. El aparato mide básicamente la respiración, la transpiración y los latidos del corazón mediante unas bandas que llevan unos sensores que se aplican sobre el cuerpo de la persona sometida al examen. 
De este modo, se pueden detectar posibles cambios en la respiración, presión arterial, ritmo cardiaco y respuesta galvánica de la piel, cuando se enfrenta el individuo al estrés del interrogatorio ${ }^{1}$.

El polígrafo se emplea actualmente en sesenta y ocho países (dieciséis de ellos en Latinoamérica), especialmente en causas relativas a delitos sexuales, acoso y delitos contra el patrimonio económico.

Su utilización se centra particularmente en los organismos de inteligencia (en investigación policial y su uso es habitual por agencias de inteligencia y diversas policías como el FBI, la CIA y la KGB), en agencias privadas de seguridad, para la selección de personal y para investigaciones al interior de las empresas privadas, $\mathrm{y}$, además, sirve como prueba judicial, específicamente en Guatemala y Panamá2.

Al respecto se afirma:

[...] En los países que admiten el polígrafo como prueba lícita, entre ellos Estados Unidos, donde se le reconoce fiabilidad y licitud, Panamá México, República Dominicana y Guatemala, por vía de ejemplo, la práctica de los Tribunales exige leer al imputado sus derechos, para que no pueda alegar coacción o imposición, pues requiere su consentimiento. Así, además de la aceptación libre, voluntaria e informada, otras reglas o requisitos tienen que ver con la presencia de su abogado, el derecho a que la prueba sea suspendida a solicitud del examinado y a que conste la firma del experto y del sujeto examinado.

En cambio, en España, al igual que en Alemania, Italia y Francia, no se admite como prueba válida ante los Tribunales. Los Tribunales españoles consideran que el polígrafo convierte al acusado en objeto del proceso, afecta la inviolabilidad de su conciencia y constituye una especie de cuasi-tortura, por lo cual con su aplicación se afecta el principio de proporcionalidad, en cuanto implica una injerencia o ataque a la indemnidad psicofísica del examinado ${ }^{3}$.

La fiabilidad del mismo también ha sido objeto de críticas por los expertos, al considerar que existen seres humanos capaces de controlar sus emociones, y por ello,

1 Eduardo de Urbano Castrillo y Miguel Ángel Torres Morato. La prueba ilícita penal. Estudio Jurisprudencial, xxx, Thomson-Aranzadi, 2007, p. 187.

2 Diana Milena Castillo Ruíz y Olga lucía Girón Herrera. Viabilidad del polígrafo como elemento material de prueba en el sistema penal acusatorio "Ley 906 de 2004", Bogotá, Universidad Militar Nueva Granada, Especialización en Procedimiento Penal Constitucional y Justicia Militar, 2012, p. 25.

3 De Urbano Castrillo y Torres Morato. Ob. cit., p. 188. 
dicen, escapan al polígrafo los sujetos hiperactivos incapaces de verse afectados por la diferenciación entre preguntas relevantes y las que son de control. Además, la psicología de cada persona es distinta y no todos actúan igual ante los mismos estímulos, pues el mayor o menor nerviosismo o incomodidad que para cada persona en concreto supone este tipo de pruebas, implica reacciones muy difíciles de discriminar.

En Colombia la normatividad lo admite en el ámbito laboral para efecto de selección de personal, e incluso como método de investigación de injustos al interior de las organizaciones empresariales, sin que la negativa a someterse al mismo, o el resultado adverso tras su práctica, pueda ser utilizada como un motivo válido o justa causa para justificar el despido de un empleado.

En algunos casos específicos la ley permite hacer pruebas de polígrafo a los aspirantes para acceder a un empleo, pero nunca para determinar una desvinculación. Entre ellos se destacan los siguientes:

Empresas de Vigilancia y Seguridad Privada (Resolución 2593 de 2003 de la Superintendencia de Vigilancia y Seguridad Privada).

Artículo $1^{\circ}$. Ámbito de aplicación. La presente resolución se aplica a todos los servicios de vigilancia y seguridad privada autorizados por la Superintendencia de Vigilancia y Seguridad Privada.

Parágrafo. Autorícese a los servicios de vigilancia y seguridad privada a que implementen en los procesos de selección de personal, el examen psicofisiológico de polígrafo, sin perjuicio de los demás requisitos exigidos para el ingreso".

Y,

Provisión de empleos de libre nombramiento y remoción, en la Unidad Administrativa Especial de la DIAN (Resolución 000014 de 2012), "Por la cual se crea el Órgano Técnico de Evaluación de Competencias Laborales para la provisión de empleos de libre nombramiento y remoción), que permite igualmente el uso del polígrafo para selección de personal".

Por su parte, el Código Nacional de Policía (Dcto. 1355 de 1970) dispone que en el marco de las asociaciones constituidas para prestar servicios de vigilancia privada, se podrán adelantar investigaciones. Así, el artículo 54 de dicha normatividad señala que:

... la investigación privada puede encaminarse a coadyuvar el descubrimiento de hechos relativos a infracciones penales siempre que no interfiera la función judicial. Los resultados de las pesquisas podrán ofrecerse al juez correspondiente. 
Y el artículo 55 del mismo estatuto, indica que

La vida íntima de persona ajena a sindicación penal no podrá ser objeto de investigación privada o judicial. Sin embargo, podrán realizarse indagaciones privadas con fines laborales o comerciales ${ }^{4}$.

Bajo tal forma de entendimiento, en el ámbito laboral es posible utilizar el polígrafo como método de selección de personal, pero sus resultados, cuando se practica a un trabajador, no pueden ser usados como prueba para determinar su responsabilidad en una falta o violación al contrato, el reglamento o el Código Laboral. Al no ser los resultados del polígrafo una prueba válida para determinar una causal de despido, tampoco se puede obligar al trabajador a practicarse dichas mediciones psicofísicas en el polígrafo, ya que su exigencia insistente podría ser considerada "acoso laboral".

Debe precisarse, sin embargo, que tal punto de vista fue legalmente matizado y encuentra, por tanto, una relevante excepción en el artículo 38 de la Ley 1621 de 2013 (Ley Estatutaria de Inteligencia y Contrainteligencia), conforme al cual los resultados del polígrafo, como prueba de confiabilidad a los servidores públicos que prestan sus servicios en los organismos de inteligencia, pueden utilizarse como fundamento para la desvinculación del mencionado personal, es decir, como prueba del despido justificado.

Ahora bien, en el ámbito del proceso penal, la Sala Penal de la Corte Suprema de Justicia ha sostenido en reiterada y homogénea línea jurisprudencial que será explicada más adelante, que el polígrafo constituye un procedimiento contrario a la dignidad de la persona humana, por cuanto la instrumentaliza cuando se somete al "detector de mentiras", despojando al juez de su facultad de valorar las pruebas, y concretamente el testimonio o la versión del investigado, con apoyo en los principios de la sana crítica, entregando la determinación de los criterios de credibilidad del testimonio al analista del polígrafo, en desmedro de la función judicial. Y ello es así, conforme a la referida jurisprudencia, porque el polígrafo no tiene como finalidad la demostración de un hecho procesal sino ofrecer un dictamen acerca de si un sujeto sometido a un interrogatorio dice o no la verdad en las respuestas a las preguntas que se le formulan. Añade la Corte objeciones relacionadas con la fiabilidad o confiabilidad del polígrafo.

En tal sentido, de acuerdo con la jurisprudencia de la Sala Penal de la Corte, se evidencian

4 Corte Suprema de Justicia. Sala de Casación Penal. Sentencia de Tutela 10.646, del 5 de febrero de 2002, M. P.: JoRge E. CóRdobA POVEdA. 
... peligros enormes frente a la libertad y a la dignidad del sujeto si se admite la utilización del polígrafo como medio de prueba, pues ese dispositivo antes que matizar la tensión entre la finalidad del proceso penal como método de aproximación a la verdad y la de proteger la integridad de los derechos fundamentales comprometidos, contribuye a afianzar más el fin que los medios, debido al dramático proceso de instrumentalización a que se somete a la persona, de quien se extraen mediciones tomadas del monitoreo de las reacciones del sistema nervioso autónomo, para convertir al propio individuo en instrumento de corroboración de una verdad a la que debe llegar la administración de justicia con absoluto respeto por la dignidad humana (cursiva fuera de texto).

Pese a ello, tal punto de vista jurisprudencial debería ser reconsiderado, toda vez que el mismo se percibe distante y alejado no sólo de los estándares internacionales en materia de Derechos Humanos que vinculan la actuación de los poderes públicos, sino de los principios generales de derecho probatorio en materia procesal penal e incluso del ordenamiento jurídico en general, que ya le reconoce en algunos eventos específicos la categoría de prueba a los resultados del polígrafo, como ocurre en el caso de las pruebas de confiabilidad a que se refiere la Ley de Inteligencia y Contrainteligencia (arts. 38 de la Ley 1621 de 2013 y 20 del Decreto 857 de 2014).

Y en efecto, el Pacto Internacional de Derechos Civiles y Políticos, que hace parte de los estándares convencionales que integran el bloque de constitucionalidad, establece en su artículo 7. ${ }^{\circ}$ que "nadie será sometido a torturas ni a penas o tratos crueles, inhumanos o degradantes. En particular, nadie será sometido sin su libre consentimiento a experimentos médicos o científicos" (cursiva fuera de texto), de lo cual se deriva como norma que el consentimiento libre, consciente e informado del testigo o versionado para someterse al polígrafo, a efecto de acreditar la conformidad de su dicho con la realidad, y en algunos casos demostrar su inocencia, no puede ser limitado por vía jurisprudencial, dado que tal experimento científico se encuentra avalado de manera general con apoyo en la disposición del citado estándar, razón por la cual la referida jurisprudencia de la Corte no está en sincronía con el Orden Público Internacional de los Derechos Humanos.

Adicionalmente, y como un argumento de refuerzo, el polígrafo se encuentra respaldado y tiene como asidero jurídico el principio general de libertad probatoria, establecido en las leyes procesales penales, disciplinarias y, muy especialmente, en el Código General del Proceso, las cuales le permiten al sujeto procesal, o parte, probar los hechos de cualquier forma que no conculque derechos y garantías, tomando en consideración, además, la necesidad de acudir a nuevos métodos y medios de prueba para hacer más eficaz una investigación.

Si bien es cierto que el principio de libertad probatoria tiene como límite los derechos fundamentales que resulten afectados, en especial el de la dignidad humana, 
tal premisa no es aplicable al asunto debatido, puesto que la dignidad humana queda indemne en la medida en que la práctica del polígrafo debe ser necesariamente consecuencia de una decisión libre, voluntaria e informada de quien se va a someter al examen, como requisito ineludible de legalidad del mismo.

En tercer lugar, ya el artículo 38 de la Ley de Inteligencia y Contrainteligencia (Ley 1621 de 2013), y el artículo 20 de su Decreto Reglamentario 857 de 2014, permiten no sólo que en los exámenes de ingreso de personal a los organismos de inteligencia se apliquen las pruebas de polígrafo, sino también en las evaluaciones periódicas, y que los resultados del mismo sean tenidos en cuenta como criterio para la desvinculación de los miembros que laboren en tales entidades.

Siendo ello así, es la misma normatividad legal la que ya está reconociendo a los resultados del polígrafo la naturaleza de medio de convicción para sustentar decisiones de carácter jurídico, tal como la desvinculación del miembro de un cuerpo de inteligencia, luego, entonces, no se advierte razón alguna que torne inexorable su exclusión para demostrar hechos, circunstancias, elementos y aspectos fundamentales en el ámbito del proceso penal y disciplinario.

\section{LAS LÍNEAS JURISPRUDENCIALES SOBRE EL TEMA. SUS CRÍTICAS}

La Sala Penal de la Corte Suprema de Justicia ha sido adversa a la admisión del polígrafo como prueba, resaltando en su jurisprudencia lo que para este trabajo resulta relevante: que su inadmisibilidad deriva de que el

... concepto de libertad probatoria que gobierna la materia está inescindiblemente ligado a la aptitud para demostrar hechos, elementos o circunstancias de la conducta punible y sus consecuencias, y no propiamente para establecer si un testigo dice la verdad o no, o si sus afirmaciones son creíbles... [lo cual constituye su objeto].

Lo que conllevaría, en razón de la valoración necesaria mediante las reglas de la sana crítica, toda vez que "el examen sobre la credibilidad de los testigos constituye una atribución privativa e insustituible del juez o fiscal según el caso", a que la prueba del polígrafo fuera desconocida, puesto que la "valoración acerca de la credibilidad del testigo y también del sindicado o acusado cuando declara, se halla estrictamente diferida al funcionario judicial (fiscal o juez)".

En fin, respecto del polígrafo, "es claro que su diagnóstico se refiere a la credibilidad del interrogado y no a la comprobación de hechos, elementos o circunstancias de la conducta investigada", por lo que 
... la prueba de polígrafo se encamina a sustituir al juez en su labor de valoración del testimonio, pues aquél no tiene como finalidad la demostración de un hecho procesal sino la de ofrecer un dictamen acerca de si un sujeto sometido a un interrogatorio dice o no la verdad en las respuestas a las preguntas que se le formulan [en tanto] la función de apreciación del testimonio atribuida al funcionario judicial quedaría subordinada a los resultados del polígrafo. Bien podría objetarse a este planteamiento que el funcionario judicial es libre para separarse de ese diagnóstico, pero en ese caso su tarea ya no estaría enfocada en apreciar la prueba testimonial haciendo uso de las reglas que la ley le impone sino en examinar el rigor técnico con que se practicó el polígrafo para deducir si se aviene o no con su conclusión.

Por tanto, si el polígrafo

... contribuye a afianzar más el fin que los medios, debido al dramático proceso de instrumentalización a que se somete a la persona, de quien se extraen mediciones tomadas del monitoreo de las reacciones del sistema nervioso autónomo, para convertir al propio individuo en instrumento de corroboración de una verdad a la que debe llegar la administración de justicia con absoluto respeto por la dignidad humana, su utilización resulta contraria al orden jurídico.

En ese sentido, se acude incluso a señalar aspectos formales como que el polígrafo sería incompatible con la ritualidad del juicio oral, pues el escenario de la audiencia pública no sería el adecuado para asegurar el ambiente psicológico propicio para la prueba ${ }^{5}$.

En graves errores doctrinarios y científicos incurre la anterior línea jurisprudencial, pues:

1) Bien dicen los mejores tratadistas: el problema de la admisibilidad o inadmisibilidad de la prueba no radica en el ofrecimiento que se haga sobre la garantía de la verdad, puesto que si así fuera el primer medio que habría que rechazar, por lo deleznable, sería el testimonio; lo decisivo, entonces, en materia de utilización de determinadas técnicas de indagación, no radica en la "falta de certeza sobre la atendibilidad de sus resultados", sino en la prudencia y control en su valoración, como también en el respeto por los derechos inalienables de las personas, lo cual abre caminos para la admisión de las pruebas bajo un esquema de numerus apertus ${ }^{6}$.

5 Corte Suprema de Justicia. Sala de Casación Penal. Decisión del 1. ${ }^{\circ}$ de agosto de 2008, proceso n. ${ }^{\circ}$ 26.470. También, siguiendo tales derroteros, la decisión del 15 de mayo de 2013, M. P. Gustavo EnRIQue Malo FERnÁndeZ, Acta n. ${ }^{\circ} 148$.

6 Vittorio Denti. Estudios de derecho probatorio, Buenos Aires, Ediciones Jurídicas Europa América, 1974, pp. 268, 269 y 270. 
2) Al igual que en cualquier prueba, para una valoración técnico-científica el juez debe tener en cuenta varios criterios "[como] modos de control que posee la opinión pública frente a la obra de un experto: a. La valoración de su autoridad científica; b. La incorporación al patrimonio científico comúnmente aceptado de los métodos de investigación por él seguidos, y c. La coherencia lógica de su argumentación ${ }^{7}$;

3) Que quien está sujeto al procedimiento pueda evadir la verdad no es asunto que resulte relevante, toda vez que, incluso, como señalaba BECCARIA, muchos podían escapar de la tortura mintiendo, aun científicamente, como queda demostrado para el pentotal sódico o suero de la verdad ${ }^{8}$, y por allí para cualquier medio probatorio;

4) Como se verá en el aparte sobre la crítica científica del testimonio, de acuerdo con los conocimientos que aportan las neurociencias se trata de un problema común a la búsqueda de la verdad a partir de cualquier método;

5) Por supuesto, así como el perito no examina ni hace sus experimentos en la audiencia, al menos no necesariamente, tampoco lo debe hacer el poligrafista;

6) No es, como lo sugiere la jurisprudencia, que la prueba solo verse sobre los hechos, pues el derecho de defensa quedaría seriamente limitado si tratáramos de circunscribir el tema probatorio a los mismos y no se extendiera a las posibilidades de acreditar otros hechos indirectos que influyen en la apreciación de las pruebas en sí, como en el caso del polígrafo aquí propuesto, toda vez que "la intervención de las técnicas modernas, sea en la formación de las pruebas o en el control de su veracidad", es asunto relevante, puesto que, como se desprende de la recomendación de DENTI, en "el amplio concepto de relevancia de la prueba se incluye también un control de verosimilitud"'9 (cursiva fuera de texto);

7) De hecho, el mismo Código de Procedimiento Penal, Ley 906 de 2004, dispone en su artículo 375 que la pertinencia de la prueba incluye, entre otros aspectos, hechos relacionados con "la credibilidad de un testigo o perito", y

8) Si resulta admisible introducir en el proceso el testimonio de los expertos mediante su criterio técnico, o el del "assessor" que como "experto asiste al juez en el examen de cuestiones técnicas" 10 , por qué no también al poligrafista.

7 DENTI. Ob. cit., p. 302.

8 Cfr. MichIO KAKU. El futuro de nuestra mente. El reto científico para entender, mejorar y fortalecer nuestra mente, Juan Manuel Ibeas Delgado y Marcos Pérez Sánchez (trads.), Bogotá, Penguin Random House, 2014, p. 249

9 DENTI. Ob. cit., pp. 268, 269 y 270, especialmente p. 274.

10 Denti. Ob. cit., pp. 282 y 285. 


\section{EL ESTADO DEL ARTE EN LA DOCTRINA}

En el marco de las investigaciones penales existen prohibiciones con respecto a algunos temas probatorios (hechos que no pueden ser objeto de prueba, o medios que no pueden ser utilizados para recaudar pruebas) como, por ejemplo, forzar la declaración acusatoria de la madre del imputado, así como con los métodos o técnicas de investigación que no son admisibles para la recolección o producción de la prueba como, por ejemplo, la utilización de torturas, amenazas o promesas, so pena de que la prueba recaudada sea calificada como nula de pleno derecho y se deba excluir del proceso. En tal sentido, la libertad para decidir durante la declaración no puede ser coartada por ningún acto de coacción física o moral, ya sea amenazas, promesas ilegítimas, o engaño, entre otras situaciones.

Se tiene dicho que

[...] Los estándares internacionales en materia de derechos humanos, la Constitución Política de 1991, que reconoce y protege los derechos fundamentales a la vida, integridad personal, intimidad, el secreto de las comunicaciones, etc., cuyo sustento axiológico es el reconocimiento de la dignidad humana como principio fundante del Estado, rechazan entonces las declaraciones obtenidas bajo tortura, coacción o amenaza, y las pruebas así obtenidas se consideran inexistentes, nulas de pleno derecho o cobijadas por la regla de exclusión.

De igual manera, se someten a idéntica consecuencia jurídica las pruebas incorporadas al proceso penal con vulneración del derecho a la intimidad o al secreto de las comunicaciones, como el allanamiento de domicilio o la interceptación de comunicaciones telefónicas no ordenadas por autoridad judicial, o que no se encuentren debidamente sustentadas en el juicio fáctico y jurídico que el principio de proporcionalidad exige para la validez de tales injerencias ${ }^{11}$.

Así mismo, según un sector de la doctrina, se genera idéntica consecuencia procesal cuando se aplica cualquier medio de investigación o método probatorio que de algún modo limite, anule o disminuya la libertad o capacidad de autodeterminación de la persona que emite una declaración, aún contando con su autorización o consentimiento. De ahí concluyen que en el marco del actual proceso penal, tanto la hipnosis como el narcoanálisis o suero de la verdad, e incluso el detector de mentiras o polígrafo, son métodos de investigación prohibidos ${ }^{12}$.

11 Francisco Farfán Molina. La prueba ilícita en el proceso disciplinario, Bogotá, Procuraduría General de la Nación e Instituto de Estudios para el Ministerio Público, 2007, pp. 30 a 34.

12 Cfr. Manuel Miranda Estrampes. El concepto de prueba ilícita y su tratamiento en el proceso penal, Barcelona, Bosch Casa Editorial, 1999, p. 37. Al respecto señala JULIO MAIER: "La volunta- 
En tal contexto, se considera ilícita la prueba obtenida mediante la utilización de métodos capaces de influir en la libre autodeterminación o de alterar la capacidad de recordar o valorar el hecho, así se practiquen con el consentimiento del imputado, pues implican una injerencia grave en espacios de libertad no disponibles ${ }^{13}$.

\section{Según Alarcón y CADEnA,}

... dentro de tal espectro se incluyen las pruebas obtenidas mediante el narcoanálisis, el hipnotismo y a través del polígrafo o detector de mentiras. Varios de estos medios pueden acarrear serias lesiones orgánicas o psíquicas, y aun cuando no las produzcan, su ilicitud es manifiesta, pues atentan contra la dignidad de la persona humana y vulneran los principios de lealtad y probidad de la pruebas, así como la intimidad y libertad humanas.

El narcoanálisis, como lo indican los citados autores,

[...] consiste en someter al paciente, por medio de una sustancia química, por ejemplo amital, pentotal, privenal, entre otras, a una ligera narcosis, que hace efecto en el sistema nervioso y le produce una relajación de la conciencia, sin suprimir las funciones expresivas de sus ideas. Pero, con dicho quebranto a su autonomía, el sujeto pierde el control sobre lo que narra, y así cualquier elemento de represión en la exteriorización del estado de ánimo, que por su euforia llega a la supresión de inhibiciones que derivan en la falta de control consciente de las declaraciones y a expansiones verbales que en algunos casos contradicen la verdad real de lo acontecido ${ }^{14}$.

Conviene advertir que el narcoanálisis y el empleo de otras drogas o métodos químicos utilizados irregularmente,

... pueden causar alucinaciones y estados altamente sugestivos, con los cuales el interrogador puede llevar al interrogado a decir lo que quiere o le insinúa, produciéndose así falsas declaraciones y errores judiciales subsiguientes, pues puede ocurrir que el sujeto narre los hechos como producto de las imágenes

riedad de la declaración del imputado no puede ser menoscabada por medio alguno que la excluya (administración de psicofármacos, sueros de la verdad o hipnosis). También otros métodos, que no suprimen la voluntariedad del acto sino que afectan la libertad de decidir aquello que se informa, están incluidos en las prohibiciones probatorias, como los detectores de mentiras o polígrafos que registran reacciones inconscientes o reflejos condicionados" (cursiva fuera de texto). Julio B. J. MaIER. Derecho Procesal Penal, t. I, Fundamentos, Buenos Aires, Editores del Puerto, 1999, p. 666.

13 La jurisprudencia estadounidense le otorga validez a la prueba obtenida bajo detector de mentiras o polígrafo, siempre y cuando ella se practique con el consentimiento escrito del órgano de prueba.

14 Héctor Alarcón Grannobles y Raúl Cadena Lozano. Garantías constitucionales y prueba ilícita, Bogotá, Ediciones Nueva Jurídica, 2004, p. 92. 
que el interrogatorio le produce, toda vez que su conciencia se encuentra limitada y violentada por la sustancia que se le ha suministrado ${ }^{15}$.

El polígrafo, por su parte, es un aparato diseñado para realizar mediciones en aquellas áreas biológicas sobre las cuales se dice que el hombre carece de dominio, como la función circulatoria y respiratoria. Este progreso técnico permite registrar e imprimir esas oscilaciones y reacciones respiratorias y circulatorias, así como las variaciones de la presión arterial, el pulso y la secreción transpiratoria, construyendo con ellas una gráfica que puede ser interpretada por el experto, quien, de acuerdo con las variaciones eléctricas que se presentan en el cuerpo del imputado, testigo o perito, y los parámetros de la sicometría, determinará si el respectivo relato se ajusta a la verdad ${ }^{16}$.

En tal sentido, conforme a la postura de HÉCtOR Alarcón GrannObles y RAúl Cadena Lozano, al igual que Alfonso Rodríguez Orlando,

[...] En el marco jurídico colombiano, se considera ilícita la prueba obtenida mediante utilización del polígrafo, por ser contraria a la dignidad de la persona humana, al derecho fundamental a no declarar contra sí mismo, y al debido proceso probatorio, según el cual solo se estima válida la prueba obtenida de manera legal, y porque además, es una prueba no confiable, ya que son muchas las causas que motivan las mutaciones psico-fisiológicas, como el temor al interrogatorio.

Por otro lado, el llamado "detector de mentiras" restringe de manera irrazonable la libertad del interrogado, pues la respuesta a los interrogantes debe estar enmarcada en monosílabos. Por la forma en que está diseñado el aparato, registra sólo respuestas negativas o afirmativas, coartando la libertad de expresión y el derecho a la defensa constitucionalmente reconocidos, lo que impide una versión judicial libre y espontánea ${ }^{17}$.

Por su lado, José I. CAFferata Nores y Maximiliano Hairabedián, señalan que

... el examen del polígrafo por su naturaleza representa un proceso de evaluación de tipo confrontativo, que genera miedo, tensión y angustia, y por eso la técnica en la construcción de la pregunta, en donde juegan la semántica, la discrecionalidad y la intención del cuestionario, constituyen una vertiente importante para evitar los resultados falsos.

15 Alarcón Granobles y Cadena Lozano. Ob. cit., p. 92.

16 Ibíd., p. 93.

17 Orlando Alfonso Rodríguez. Prueba ilícita penal, Bogotá, Ediciones Jurídicas Gustavo Ibáñez, 2003, pp. 139 a 141. 
Prospectivamente agregan que "quizás existan o puedan desarrollarse otras técnicas que proporcionen criterios para distinguir una declaración falsa de una verdadera", apareciendo como tal en la actualidad, para lo cual se reclama estudio

... la neuroimagen psiquiátrica o funcional, que con el apoyo de programas informáticos ha permitido analizar minuciosamente y simular la función global del cerebro, obteniéndose una especie de "mapa" en el que se refleja, mediante contraste, el nivel de oxigenación de la sangre, detectándose los aumentos en la función cerebral y cambios localizados en la actividad intelectual. En fin, “en oposición al polígrafo tradicional -que mide la respuesta emocional del sujeto ante una mentira-la neuroimagen detectaría el proceso mental mismo de la mentira. Más aún, a diferencia del polígrafo -en el cual el individuo puede ser entrenado para suprimir una respuesta emocional a la mentira- en la neuroimagen el sujeto no puede controlar su actividad cerebral para evitar la detección. Y así como con la mentira ciertas regiones del cerebro se "encienden" durante el escaneo, lo mismo ocurre cuando el sujeto observa un rostro humano que le es familiar, aún prescindiendo de expresiones o intentos del sujeto para ocultarlo ${ }^{18}$ (cursiva fuera de texto).

Finalmente De Urbano Castrillo y Torres Morato, advierten que

[... La utilización del suero de la verdad representa una intervención corporal, cuyo objetivo estriba en suministrar sustancias narcóticas al testigo o declarante, para que afloren y se verbalicen contenidos inconscientes mediante la acción que tales sustancias tienen sobre el yo al liberar frenos y defensas, desligando de sus autocontroles al sujeto, ya que se parte de la tesis de que el subconsciente no puede mentir.

En la sentencia del Tribunal Supremo de fecha 22 de mayo de 1982 (RJ 1982, 2702) se indica que la admisión indiscriminada del narcoanálisis conculcaría el principio de legalidad y supondría una forma indirecta y torticera de obtener la confesión del reo, en cuanto significa un desprecio a la persona humana y el aniquilamiento de los resortes físicos y psíquicos del ser humano.

La sentencia del 26 de noviembre de 1991 (Rj 1991, 8562), ya no deja resquicios abiertos, en cuanto establece que la confesión obtenida mediante tortura, hipnosis o sueros de la verdad está prohibida implícitamente por el artículo 15 de la Constitución, no aceptándose siquiera cuando es el propio imputado el que solicita estos medios de prueba, ya que la dignidad humana es innegociable al tratarse de pruebas que afectan la libertad de la declara-

18 José I. Cafferata Nores y Maximiliano Hairabedián. La prueba en el proceso penal, Buenos Aires, Edit. Lexis Nexis, 2008, pp. 136 a 138. 
ción, la cual falta en estos casos, por lo que sólo son factibles en el mundo del psicodiagnóstico y de la psicoterapia.

El polígrafo, en la misma línea de razonamiento, es un método que suprime o disminuye las facultades de conocimiento, discernimiento y decisión del ser humano, y en virtud de ello la jurisprudencia de los Tribunales españoles no lo admiten como pruebe válida ${ }^{19}$.

\section{DE LOS ARGUMENTOS QUE SUSTENTAN LA JURIDICIDAD DE ADMITIR LA UTILIZACIÓN DEL POLÍGRAFO EN EL PROCESO PENAL}

Varios son los argumentos que se pueden utilizar en pro del reconocimiento del polígrafo como prueba, medio probatorio o instrumento de auxilio en la valoración de la prueba; no obstante, queremos centrarnos en aquellos que jurídicamente le otorgan legitimidad y viabilidad jurídica.

\section{A. Polígrafo y bloque de constitucionalidad. El control de convencionalidad}

Dado el valor jerárquico de los tratados internacionales, por supuesto respetando siempre la interpretación y aplicación de los mismos a partir de la determinación y escogencia vinculante del mejor estándar de garantías que rija una determinada materia, se ha esbozado un concepto jurídico que cada día toma mayor fuerza, según el cual es obligación de toda autoridad de un Estado nacional, pero muy especialmente si la misma tiene la calidad de juez en sentido formal y/o material, de confrontar y contrastar las normas nacionales e internacionales con el fin de ejercer un control de convencionalidad ${ }^{20}$ como muestra real, eficaz y eficiente de respeto hacia el valor del Orden Público Internacional de los Derechos Humanos.

En efecto, se ha dicho por la Corte Interamericana de Derechos Humanos que

... el poder judicial debe ejercer una especie de control de convencionalidad entre las normas jurídicas internas que aplican en los casos concretos y la Convención Americana sobre Derechos Humanos. En esta tarea el poder judicial debe tener en cuenta no solamente el tratado, sino la interpretación que del mismo ha hecho la Corte Interamericana, intérprete última de la Convención Americana ${ }^{21}$.

19 De Urbano Castrillo y Torres Morato. Ob. cit., pp. 186 a 189.

20 Cfr. el Salvamento de Voto del Magistrado Néstor Osuna Patiño a la sentencia de tutela de segunda instancia la Sala Jurisdiccional Disciplinaria del Consejo Superior de la Judicatura caso Petro, M. P.: Pedro Alonso Sanabria Buitrago, radicación n. o 11001110200020130812001.

21 Corte Interamericana de Derechos Humanos. Sentencia del 24 de noviembre de 2006, Caso Trabajadores cesados del Congreso vs. Perú, párrafo 128. 
Ese control de convencionalidad es obligatorio, especialmente cuando se alegan mejores garantías a partir del Orden Público Internacional de los Derechos Humanos, toda vez que, como dice el órgano judicial de supervisión antes señalado, "cuando una cuestión ha sido resuelta definitivamente en el orden interno según las cláusulas de la Convención, no es necesaria traerla a esta Corte para su aprobación o confirmación"22.

Así las cosas, la definición de un asunto por parte de los poderes públicos de los Estados nacionales, incluyendo el poder judicial, deben atender el control de convencionalidad so pena de la intervención de los órganos de supervisión internacional sobre Derechos Humanos.

Recientemente la Corte Interamericana de Derechos Humanos ha señalado ${ }^{23}$ :

[... 142. La responsabilidad estatal bajo la Convención sólo puede ser exigida a nivel internacional después de que el Estado haya tenido la oportunidad de declarar la violación y reparar el daño ocasionado por sus propios medios. Esto se asienta en el principio de complementariedad (subsidiariedad), que informa transversalmente el Sistema Interamericano de Derechos Humanos, el cual es, tal como lo expresa el Preámbulo de la misma Convención Americana, "coadyuvante o complementario de la [protección] que ofrece el derecho interno de los Estados americanos". De tal manera, el Estado "es el principal garante de los derechos humanos de la personas, de manera que, si se produce un acto violatorio de dichos derechos, es el propio Estado quien tiene el deber de resolver el asunto a nivel interno y [en su caso] reparar, antes de tener que responder ante instancias internacionales como el Sistema Interamericano, lo cual deriva del carácter subsidiario que reviste el proceso internacional frente a los sistemas nacionales de garantías de los derechos humanos" 24 .

Esas ideas también han adquirido forma en la jurisprudencia reciente bajo la concepción de que todas las autoridades y órganos de un Estado Parte en la Convención tienen la obligación de ejercer un "control de convencionalidad" 25 .

22 Corte Interamericana de Derechos Humanos. Sentencia del 6 de diciembre de 2001, Caso "Las Palmeras" vs. Colombia, párrafo 33.

23 Corte Interamericana de Derechos Humanos. Sentencia del 30 de noviembre de 2012, Caso Masacre de Santo Domingo vs. Colombia.

24 Caso Acevedo Jaramillo y otros vs. Perú. Interpretación de la Sentencia de Excepciones Preliminares, Fondo, Reparaciones y Costas. Sentencia del 24 de noviembre de 2006, párr. 66.

25 Cuando un Estado es Parte de un tratado internacional como la Convención Americana, todos sus órganos, incluidos sus jueces, están sometidos a aquél, lo cual les obliga a velar por que los efectos de las disposiciones de la Convención no se vean mermados por la aplicación de normas contrarias a su objeto y fin, por lo que los jueces y órganos vinculados a la administración de justicia en todos los niveles están en la obligación de ejercer ex oficio un "control de convencionalidad" entre las normas 
143. Lo anterior significa que se ha instaurado un control dinámico y complementario de las obligaciones convencionales de los Estados de respetar y garantizar derechos humanos, conjuntamente entre las autoridades internas (primariamente obligadas) y las instancias internacionales (en forma complementaria), de modo que los criterios de decisión puedan ser conformados y adecuados entre sí.

Se afirma por la doctrina especializada que

... el fundamento normativo de este control de convencionalidad estaría en el art. 2. ${ }^{\circ}$ de la Convención Americana, de acuerdo con el cual los Estados partes en ese tratado tienen la obligación de armonizar el derecho interno con las disposiciones de esa convención ${ }^{26}$.

Resulta obvio tal control, puesto que, a nivel convencional, existe la obligatoriedad de instrumentar medidas legislativas y judiciales para hacer efectivos los derechos fundamentales (arts. 2. ${ }^{\circ}$ num. $2 .^{\circ}$ del Pacto Internacional de Derechos Civiles y Políticos, y 2. ${ }^{\circ}$ de la Convención Americana sobre Derechos Humanos).

Sólo así se garantizan los derechos que emanan del fundamental a la libertad de que dan cuenta los instrumentos convencionales que prevalecen en el orden interno y condicionan la interpretación de derechos y deberes constitucionales de los Estados Partes (arts. 4. ${ }^{\circ}$ y 93 de la Carta Política, y 29 de la Convención Americana sobre Derechos Humanos).

La aparente contradicción entre leyes internacionales y nacionales no existe, puesto que, en aplicación del artículo 93 de la Carta Política, aquellas se encuentran incorporadas a nuestro ordenamiento jurídico con rango constitucional.

Es en tal sentido que ha dicho la Corte Constitucional:

internas y la Convención Americana, evidentemente en el marco de sus respectivas competencias y de las regulaciones procesales correspondientes, y en esta tarea, deben tener en cuenta no solamente el tratado, sino también la interpretación que del mismo ha hecho la Corte Interamericana, intérprete última de la Convención Americana. Cfr. Caso Almonacid Arellano y otros vs. Chile. Excepciones Preliminares, Fondo, Reparaciones y costas. Sentencia del 26 de septiembre de 2006 . Serie C n. ${ }^{\circ} 154$, párr. 124; Caso Gomes Lund y otros (Guerrilha do Araguaia) vs. Brasil. Excepciones Preliminares, Fondo, Reparaciones y Costas. Sentencia del 24 de noviembre de 2010. Serie C n. ${ }^{\circ} 219$, párr. 176, y Caso Cabrera García y Montiel Flores vs. México. Excepción Preliminar, Fondo, Reparaciones y Costas. Sentencia del 26 de noviembre de 2010. Serie C n. ${ }^{\circ} 220$, párr. 225. Cfr., asimismo, Caso Gelman vs. Uruguay. Fondo y Reparaciones. Sentencia del 24 de febrero de 2011 Serie C n. ${ }^{\circ} 221$, párr. 193.

26 Cfr. Xiomara Lorena Romero Pérez. Vinculación de las resoluciones judiciales de la Corte Interamericana, Bogotá, Universidad Externado de Colombia, 2011, p. 63. 
La conformidad de la legislación interna con los tratados internacionales y con las obligaciones contraídas por el Estado colombiano con otros estados o con entidades supranacionales es exigida con mayor rigor por la Constitución Política cuando se trata de la aplicación y el ejercicio de los derechos fundamentales, según resulta con nitidez meridiana del artículo 93 de la Carta Política, a cuyo tenor los tratados y convenios internacionales que hubiere aprobado el Congreso y ratificado el Ejecutivo, mediante los cuales se reconocen los derechos humanos y en los que se prohíbe su limitación en los estados de excepción, prevalecen en el orden interno ${ }^{27}$.

\section{B. El consentimiento informado como fundamento del Polígrafo, de acuerdo con los instrumentos convencionales de Derechos Humanos}

Conforme al artículo 7. ${ }^{\circ}$ del Pacto Internacional de Derechos Civiles y Políticos de la ONU, Ley 74 de 1968, "nadie será sometido a torturas ni a penas o tratos crueles, inhumanos o degradantes. En particular, nadie será sometido sin su libre consentimiento a experimentos médicos o científicos" (cursiva fuera de texto).

Es claro que dicho texto, de manera categórica y contundente, erige al consentimiento libre e informado como presupuesto esencial para la práctica de experimentos o intervenciones corporales con diversos fines.

El polígrafo es un instrumento científico ultrasensible y de gran precisión, capaz de registrar de forma continua y simultánea en un gráfico las variaciones fisiológicas que se producen en el organismo de un individuo estimulado psicológicamente mediante determinadas preguntas.

En ese orden de ideas, el polígrafo es, en esencia, un experimento científico encaminado a establecer y evaluar unas reacciones corporales que se producen en circunstancias de tensión ocasionadas por las afirmaciones contrarias a la realidad, y, en tal sentido, es el consentimiento libre y consciente de quien se va a someter al mismo el que valida y otorga licitud a tal método, como bien lo señala el Pacto Internacional de Derechos Civiles y Políticos, sin que sea posible para los jueces colombianos, en virtud del control de convencionalidad, elaborar interpretaciones jurisprudenciales que desconozcan o ignoren el citado estándar.

La misma línea jurisprudencial de la Corte Constitucional colombiana sobre consentimiento informado ha señalado de manera reiterada que

... la exigencia del consentimiento resulta de la consideración del individuo como un agente moral autónomo, capaz de decidir por sí mismo en los dis-

27 Corte Constitucional. Sentencia C-073 de 1996, M. P.: HeRnÁndez Galindo. 
tintos ámbitos de la vida. Sólo él está en condiciones de adoptar decisiones relevantes relativas a su propia salud, tales como si quiere recibir o no tratamiento, asumir el riesgo de una intervención, perder un miembro u órgano, o incluso morir, pues conoce sus intereses mejor que el Estado, que en tal contexto debe respetar y proteger la autonomía personal y no interferir las acciones libres del sujeto (Sentencias T-493 de 1993, T-401 de 1994, T-559 de 1995, y T-692 de 1999) ${ }^{28}$.

Se admite así que el consentimiento constituye exigencia ineludible para llevar a efecto la actividad médica, o cualquier intervención en el cuerpo humano, incluido el polígrafo.

Es posible ejecutar, con apoyo en el consentimiento libre del enfermo terminal, incluso actos constitutivos de eutanasia activa, pasiva o indirecta (cuidados paliativos). En este plano, para que el consentimiento se estime válido y eficaz deben concurrir desde luego determinados requisitos: la eutanasia activa es la acción médica por medio de la cual se pone fin a la vida de un enfermo terminal irrecuperable, siempre y cuando este consienta el hecho. Dicho consentimiento puede expresarlo directamente por medio de un documento que se denomina "testamento vital", o a través de sus familiares cuando se encuentre en estado de inconsciencia. Es de anotar que en la Sentencia C-239 de 1997, la Corte Constitucional colombiana reconoció eficacia al consentimiento del enfermo terminal en tales hipótesis, creando una causal de justificación únicamente a favor del médico que ejecuta la eutanasia activa a solicitud del sujeto pasivo:

[...] La eficacia de consentimiento del enfermo o individuo que será sometido al experimento o intervención, se encuentra supeditada, en primer término a que el médico o encargado cumpla su correlativo deber de información, pues sólo si aquel conoce el significado, alcance, riesgos, diagnóstico, pronóstico y alternativas del tratamiento o intervención, que autoriza, el consentimiento es válido. Adicionalmente, se exige que el consentimiento sea manifestado por un paciente con capacidad natural de juicio y discernimiento, pues la eficacia del mismo dependerá de que se trate de un verdadero acto de autodeterminación.

Adicionalmente, es necesario que el consentimiento sea anterior o coetáneo, es decir, que el acto de disposición sea previo, o en casos extremos coetáneo con la afectación del bien jurídico sobre el cual se dispone, y que sea expreso, es decir, que la manifestación se realice de manera clara, precisa y seria, es decir, que por lo menos sea reconocible externamente. También la validez requiere la seriedad, concreción, y que sea emitido libre de vicios, sin error,

28 En Francisco Farfán Molina. Eutanasia, derechos fundamentales y ley penal, Bogotá, Ediciones Nueva Jurídica, 2008, pp. 269 a 274. 
dolo ni violencia. Por ello el consentimiento prestado mediante coacción es ineficaz $^{29}$.

En el anotado orden de ideas se colige que

... el consentimiento, como expresión del libre desarrollo de la personalidad, sólo puede ser limitado cuando afecte intereses ajenos o cuando exista una disposición constitucional relevante que así lo disponga. Si se mantiene su ejercicio en el marco de la libre disposición, no existe razón alguna para no reconocerle eficacia ${ }^{30}$.

Tales premisas llevan necesariamente a concluir que al considerarse el polígrafo un experimento científico, su exclusión como acto investigativo en el proceso penal sólo sería viable en los casos en que no exista consentimiento del indiciado, acusado o testigo que será sometido al mismo, o en los eventos en que tal consentimiento no reúna los requisitos y presupuestos antes mencionados.

A contrario sensu, en caso de existir tal consentimiento informado, el estándar convencional antes mencionado respalda su práctica, particularmente tratándose de un mecanismo solicitado por el reo para demostrar su inocencia.

\section{La decisión libre, voluntaria, consciente e informada de someterse al Polígrafo}

Conforme con lo señalado, si el sometimiento a la prueba técnica es consciente, voluntario e informado, no puede hablarse del quebrantamiento de la dignidad humana como fundamento del orden jurídico (art. 1. . de la Carta Política), y mucho menos puede encontrarse allí una instrumentalización del ser humano, pues no se entiende cómo durante el proceso penal sea posible renunciar a la prueba, allanarse a cargos, etc., como expresión de la legítima voluntad personal de participar en las decisiones que afectan a los ciudadanos como derecho constitucional fundamental (art. 2. ${ }^{\circ}$ ibíd..), y no resulte jurídicamente viable acudir al polígrafo como prueba de inocencia.

El que tenga que ocuparse el juez de la pericia del poligrafista no es obstáculo alguno, pues también ello debe hacerse en la valoración del peritazgo, como se demanda en el artículo 257 de la Ley 600 de 2000, y de allí la semejanza del polígrafo con la asesoría especializada, como se desprende del artículo 242 ibíd., lo cual resulta aplicable también al derecho disciplinario por virtud de lo dispuesto en los artículos 21 de la Ley 734 de 2002 y 16 de la Ley 1123 de 2007.

29 FARFÁn Molina. Eutanasia, cit., p. 266.

30 Carlos Arturo Gómez Pavajeau. Estudios de Dogmática en el nuevo Código Penal, Bogotá, Ediciones Gustavo Ibáñez, 2003,p. 160. 
Aquí lo decisivo es el prudente juicio del juez enfocado en la no vulneración de los derechos fundamentales (incs. 2. ${ }^{\circ}$ del art. 32 de la Ley 600 de 2000 y 3. ${ }^{\circ}$ del art. 86 de la Ley 1123 de 2007).

La petición del examen del polígrafo es decisión consciente, voluntaria e informada, y al ser un juicio fundado en la plenitud de su autonomía ética, no puede considerarse que exista violación alguna a sus derechos fundamentales.

No se entiende cómo, para los efectos de la eutanasia, según la Sentencia C-239 de 1997 de la Corte Constitucional, valga una decisión fundada en dichos elementos y no en el caso que aquí se discute.

En fin, no se trata, como ya se advirtió, de un medio de prueba, sino de utilizar el polígrafo como un insumo de valoración del dicho del imputado, asimilado al asesoramiento especializado del artículo 242 de la Ley 600 de 2000.

Como afirma PARRA QUIJANO, con el principio de proporcionalidad se trata de "sopesar, en el caso concreto, los derechos fundamentales en conflicto y excepcionalmente permitir la aducción de pruebas, que en otras circunstancias serían consideradas ilícitas"31.

Y es que el polígrafo es una realidad normativa en Colombia, como se desprende de un estudio serio y juicioso realizado por la Universidad de los Andes, suscrito por YinNA RinCón FONSECA ${ }^{32}$, en el cual se hace mención de los artículos $2 .^{\circ}$ de la Resolución 02593 de 2003 de la Superintendencia de Vigilancia y Seguridad Privada y 34 del Decreto 2187 de 2001 ,

El estado actual de la justicia, sometido a mercaderes de la "apariencia", reclama medidas que equilibren las injusticias que puedan recaer sobre quienes proceden lealmente y colaboran con la justicia (art. 95 num. 7 de la Carta Política), como se desprende de la norma constitucional que, por configurarse en norma de normas (art. $\left.4^{\circ}\right)$, se constituye en un estándar constitucional para otorgar validez y legitimación de tal orden al polígrafo.

Finalmente, es claro que, puesto que la decisión de someterse al polígrafo es libre, de su negativa no puede derivarse la construcción de indicios en contra del procesado, esto es, aplicar el Código de Procedimiento Civil en su artículo 249, según el cual, por virtud de la "conducta procesal de las partes", "el juez podrá deducir indicios" de la misma.

31 Jairo Parra Quijano. Manual de Derecho Probatorio, Bogotá, Librería Ediciones del Profesional, 2009 , p. 37.

32 Disponible en [https://ctp.uniandes.edu.co/Empresas/Servicios/Articulos/el_poligrafo:_una_herramie. php]. 
En efecto, en materia sancionatoria el procesado tiene derecho a "guardar silencio", y de allí surge "la prohibición de derivar de tal comportamiento indicios en su contra" (art. 337 de la Ley 600 de 2000, aplicable a las leyes 732 de 2002 por virtud de sus arts. 21 y 1123 de 2007, en razón de lo que dispone su artículo 16). Es más, como principio rector, el literal c del artículo 8. ${ }^{\circ}$ de la Ley 906 de 2004 consagra el derecho del procesado a que "no se utilice el silencio en su contra". Lo contrario sería hacer obligatorio lo que es objeto de libre voluntad, vaciando de contenido la dignidad del ser humano, contrariando por tanto las bases fundamentales del orden jurídico, en perjuicio de lo dispuesto en el artículo 1..$^{\circ}$ de la Carta Política.

Las partes no se rigen por el "deber de decir la verdad”, el cual, según CAPPELLETI, es un "instituto inquisitorio y contrario a la libre disposición de las partes, un instrumento de tortura moral" 33 , de forma que en tales condiciones, indudablemente, se respeta la dignidad del ser humano; de allí que nos encontremos frente a una renuncia al derecho de guardar silencio globalmente considerado, a través de una manifestación libre, consciente, voluntaria y debidamente informada, la cual puede incluso primar sobre el derecho a "la no autoincriminación" (art. 8. ${ }^{\circ}$ lit. 1 de la Ley 906 de 2004).

\section{Polígrafo y libertad probatoria. Técnica auxiliar para la averiguación de la verdad}

Señala la doctrina que "la declaración de inocencia de un inculpado es demasiado importante para ser sacrificada a los ídolos del procedimiento" ${ }^{34}$, lo cual se complementa con lo dicho por CAPELLETTI acerca de que

... siempre que las garantías constitucionales sean observadas, no veo, pues, por qué razón no se debería admitir que el Juez base su convicción también sobre pruebas no expresamente previstas por la ley ${ }^{35}$.

Las pruebas devienen admisibles por virtud de "las características de la propia sociedad en la que los procedimientos probatorios están destinados a ponerse en práctica", por supuesto, atendiendo también los avances científicos que la misma produce ${ }^{36}$.

Así, los artículos 233 de la Ley 600 de 2000, 130 de la Ley 734 de 2002 y 86 de la Ley 1123 de 2007 se refieren a los llamados medios de prueba, adicionando a la lista enunciativa "cualquier otro medio técnico o científico, los cuales se practicarán con-

33 Mauro Cappelleti. El Proceso Civil en el Derecho Comparado, Buenos Aires, Ediciones Jurídicas Europa América, 1973, p. 81.

34 López Barja de Quiroga, Tratado..., cit., p. 963.

35 Jacobo López Barja de Quiroga. Instituciones de Derecho Procesal Penal, Madrid, Akal/iure, 1999, p. 276.

36 DENTI. Ob. cit., pp. 85, 102 y 111. 
forme a las normas del Código de Procedimiento Penal en cuanto sean compatibles con la naturaleza y reglas del derecho disciplinario".

Y el Código General del Proceso, Ley 1564 de 2012, señala en su artículo 1. ${ }^{\circ}$ que

... se aplica, además, a todos los asuntos de cualquier jurisdicción o especialidad y a las actuaciones de particulares y autoridades administrativas, cuando ejerzan funciones jurisdiccionales, en cuanto no estén regulados expresamente en otras leyes.

Sobre la interpretación de normas procesales señala en su artículo 11:

Al interpretar la ley procesal el juez deberá tener en cuenta que el objeto de los procedimientos es la efectividad de los derechos reconocidos por la ley sustancial. Las dudas que surjan en la interpretación de las normas del presente código deberán aclararse mediante la aplicación de los principios constitucionales y generales del derecho procesal garantizando en todo caso el debido proceso, el derecho de defensa, la igualdad de las partes y los demás derechos constitucionales fundamentales. El juez se abstendrá de exigir y de cumplir formalidades innecesarias (cursiva fuera de texto).

El artículo 12, sobre vacíos normativos, expresa que se llenarán

... con las normas que regulen casos análogos. A falta de estas, el juez determinará la forma de realizar los actos procesales con observancia de los principios constitucionales y los generales del derecho procesal, procurando hacer efectivo el derecho sustancial.

En el inciso $2 .^{\circ}$ del artículo 165 se precisa que "el juez practicará las pruebas no previstas en este código de acuerdo con las disposiciones que regulen medios semejantes o según su prudente juicio, preservando los principios y garantías constitucionales".

Pero, además, en los artículos 237 de la Ley 600 de 2000, 131 de la Ley 734 de 2002 y 87 de la Ley 1123 de 2007, se consagra el principio de libertad de prueba, lo que significa que el único límite imponible en la materia es el respeto por los derechos fundamentales ${ }^{37}$.

37 "El principio de la libertad probatoria ha sido caracterizado diciendo que en el proceso penal todo puede ser probado, y por cualquier medio de prueba. Esto no significa que se haga prueba de cualquier modo -ya que hay que respetar las regulaciones procesales de los medios de prueba-, ni mucho menos a cualquier precio, pues el orden jurídico impone limitaciones derivadas del respeto de la dignidad humana u otros intereses. En relación con el objeto de prueba, es posible hacer prueba sobre cualquier hecho o circunstancia interesante para la investigación. No obstante, la prueba no puede recaer sobre hechos o circunstancias que no estén relacionados con la hipótesis que generó el proceso, de modo 
De manera contundente, el artículo 374 de la Ley 906 de 204 establece el principio de libertad de pruebas y el principio de numerus apertus en cuanto a la consagración de pruebas legales de naturaleza técnica o científica, con tal de que "no viole los derechos humanos". Así lo ratifica también el artículo 382, sobre los "medios de conocimiento".

No es del todo correcto decir que prueba es solo aquello que demuestra un hecho, elemento o circunstancia, puesto que: i. Se discute arduamente si en tal sentido el indicio es un medio probatorio, lo cual afirma el inciso $1 .^{\circ}$ del artículo 233 de la Ley 600 de 2000 (también lo hacía el art. 258 del C. de P. P. de 1987), empero, lo niegan los incisos 2. ${ }^{\circ}$ del artículo 86 de la Ley 1123 y $2 .^{\circ}$ del artículo 130 de la Ley 734 de 2002, y lo hacía el artículo 248 del C. de P. P. de 1991; el actual C. de P. P., Ley 906 de 2004, ni siquiera se refiere al indicio, con lo cual se demuestra que no existen imponderables en la materia, puesto que, es innegable, el indicio es un razonamiento, y sólo se refiere al hecho, elemento o circunstancia el llamado hecho indicador; ii. Además de hechos, elementos y circunstancias, también la prueba se refiere a "estados", tal como lo reconoce el artículo 244 de la Ley 600 de 2000, lo cual es absolutamente evidente cuando se trata de los llamados indicios de inimputabilidad y culpabilidad; iii. Por ende, en materia de inimputabilidad, el peritazgo se refiere a un "estado" y no a hechos, elementos o circunstancias, y iv. Es evidente que tampoco se refieren a ello las operaciones técnicas y el juramento estimatorio (arts. 247 y 278 de la Ley 600 de 2000).

Dicho pensamiento deriva de épocas fundadas en la responsabilidad objetiva, ancladas en el puro elemento físico, pues la prueba se refería al "hecho" (muy especialmente los arts. 217, 218 y 221 del C. de P. P. de 1938), lo cual no encaja con la fase culpabilista fundada en la responsabilidad, que se inauguró con el Código Penal de 1980 y se refinó con el destierro de la palabra "hecho" y su reemplazo por la expresión "conducta" (Ley 599 de 2000).

Tal distinción es evidente puesto que, de no hacerla, al interpretar literal, gramatical y exegéticamente la expresión "elementos físicos materia de prueba” se pensaría que sólo lo físico es objeto de prueba (art. 288 de la Ley 600 de 2000).

directo o indirecto. Además, hay ciertos temas sobre los cuales no se puede probar por expresa prohibición de la ley -como es el caso de imputación de injuria relacionada con la vida sexual, conyugal o de familia del sujeto pasivo. En relación con los medios de prueba, la libertad probatoria significa que no se exige la utilización de un medio determinado para probar un objeto específico, y si bien se debe recurrir al que ofrezca mayores garantías de eficacia, el no hacerlo carece de sanción alguna, y no impide el descubrimiento de la verdad por otros medios. Así, es posible hacer prueba no sólo con los medios expresamente regulados, sino con cualquiera otro no reglamentado, siempre que sea adecuado para descubrir la verdad. Cada prueba se ajustará al trámite asignado, y cuando se quiera optar por un medio probatorio no previsto, se deberá utilizar el procedimiento señalado para el medio expresamente regulado que sea analógicamente más aplicable, según la naturaleza y modalidades de aquel, respetando sus formas": CAFFERATA Nores y HAIRABEDIÁn. Ob. cit., pp. 40 a 46. 
Entonces, es evidente que la prueba también está referida a "estados”, muy especialmente los llamados "personales”, pues así lo acredita el artículo 277 de la Ley 600 de 2000 (también el art. 294 del C. de P. P. de 1991), para lo cual se deben dejar las constancias del caso en el acta, de "la forma como hubiere declarado -el testigo- y las singularidades que puedan observarse en el testimonio", lo cual forma parte de los “criterios para la apreciación del testimonio". Así lo exigían, de manera expresa, los artículos 236 del C. de P. P. de 1971 y 295 del C. de P. P. de 1987.

Y a ello, precisamente, apunta la técnica del polígrafo, pues se dice que

... el llamado detector de mentiras, máquina de la verdad o polígrafo es un tipo particular de instrumento de medición utilizado para el registro de respuestas fisiológicas. Registra las variaciones de la presión arterial, el ritmo cardíaco, la frecuencia respiratoria y la respuesta galvánica o conductancia de la piel, que se generan ante determinadas preguntas que se realizan al sujeto sometido a la prueba. También posee la capacidad de medir parámetros como el movimiento del interrogado, de cara a evitar posibles contramedidas durante el interrogatorio [como también] la tensión emotiva que provoca el conocimiento propio de la verdad, que modifica ostensiblemente la progresión orgánica de una persona que engaña sobre un aspecto específico. Consideran, por tanto, notorios los indicadores de medida de discordancia del pensamiento, al valorar que la inexactitud conceptual en las emociones provocadas ante un tema específico y la activación compleja de neurotransmisores modifica las constantes orgánicas.

[...] cabe recalcar que el polígrafo no es un instrumento que detecte mentiras por sí mismo, aunque las nuevas unidades digitales realizan una evaluación del interrogatorio de manera autónoma, con altos ratios de fiabilidad. En cualquier caso, la evaluación final es responsabilidad del técnico poligrafista ${ }^{38}$.

El polígrafo es, en consecuencia, una técnica auxiliar para la averiguación de la verdad, por lo que queda recogida dentro de aquella teleología de las expresiones “ciencia, arte o técnica" de que da cuenta el artículo 242 de la Ley 600 de 2000. Los asesores especializados ilustran al juez en dichas precisas materias, el cual no se ve suplantado, sino por el contrario, asesorado en un tópico muy especial y definitivo para la valoración de la prueba.

Sin embrago, los asesores especiales no son peritos, ni el polígrafo no proporciona un peritazgo, por lo que, en consecuencia, cabe dentro de la teleología del mencionado artículo 242, pues se refiere a que ellos “tomarán posesión como los peritos”, pero es evidente que no lo son, puesto que tal artículo no pertenece a los capítulos sobre las pruebas en concreto, sino a aquel referido a los "Principios generales" de las pruebas.

38 Cfr. [http://es.wikipedia.org/wiki/Detector_de_mentiras]. 
Significa lo anterior, que el técnico poligrafista auxilia o colabora con el juez en un tópico técnico que tiene que ver con criterios para la apreciación del testimonio, los cuales valen también para la exposición del imputado (arts. 277 y 282 de la Ley 600 de 2000). Además, existen muestras irrefutables de pruebas complejas, acompañadas de asesorías semejantes, como se aprecia en los artículos 247, 248 y 263 de la Ley 600 de 2000 y, muy especialmente, en el llamado "testigo técnico".

Por ello se registra el estado de la opinión en derecho comparado cuando se afirma que

... la técnica del polígrafo puede ser usada con seguridad, su uso no se encuentra restringido, no existe ninguna ley que regule o limite el uso y aplicación del polígrafo, se dice que mientras se respete la intimidad de la persona y que ésta, acepte libremente la aplicación de la prueba, mediante un consentimiento por escrito, no existe ningún obstáculo para su aplicación ${ }^{39}$.

En contraste con lo decidido respecto del polígrafo, la Corte Suprema de Justicia, Sala de Casación Penal, admite todavía hoy en día la diligencia de careo, que no aparece en los Códigos de Procedimiento Penal, muy a pesar de que la misma le permite al juez indagar por "la actitud, el comportamiento, la expresión y las deposiciones" de los careados -testigos y sindicados_- ${ }^{40}$, que es lo que se busca también con el polígrafo, sólo que con el acompañamiento de un experto.

\section{E. Prueba novel}

Ahora bien, en el terreno de la Ley 906 de 2004 el polígrafo podría eventualmente considerarse una prueba novel, teniendo en cuenta lo establecido en el artículo 422, sobre admisibilidad de publicaciones científicas y aspectos noveles del conocimiento. Según el citado texto, para que una opinión pericial referida a aspectos noveles del conocimiento sea admisible en el juicio, se exige como requisito que la base científica o técnica satisfaga al menos uno de los siguientes criterios:

a. Que la teoría o técnica subyacente haya sido o pueda llegar a ser verificada;

b. Que la teoría o técnica subyacente haya sido publicada y haya recibido la crítica de la comunidad académica;

c. Que se haya acreditado el nivel de confiabilidad de la técnica científica utilizada en la base de la opinión pericial, y

39 Ángela Tapias; Andrea Avendaño, Ana María Fuentes y Jenny Zaldúa. "Viabilidad de la aplicación en Colombia de las técnicas psicológicas: el polígrafo, el análisis del estrés de la voz, el análisis de contenido basado en criterios, la hipnosis y la entrevista asistida con drogas, para evaluar la credibilidad del testimonio". Disponible en [http://psicologiajuridica.org/psj97.html].

40 PARRa QuiJano. Ob. cit., p. 339. 
d. Que goce de aceptabilidad en la comunidad académica.

El problema estriba, entonces, en establecer si el examen de polígrafo, como opinión referida a aspectos noveles del conocimiento, cumple con los requisitos que la base científica o técnica exige para poder ser admisible en el juicio.

Al respecto debe indicarse que esta técnica cuenta con un gran respaldo técnico científico, puesto que existe una Asociación Americana del Polígrafo (APA), la cual confirma la validez y confiabilidad del referido método (CAPPS, [2002]. Estudios y conceptos sobre los detectores de mentiras. El poligrafista Internacional $)^{41}$.

Frente a la confiabilidad de la técnica científica utilizada, sea lo primero indicar que evidentemente se trata de una prueba en cuyo contexto la clave es la opinión del experto que utiliza el aparato y que ha de comparecer al juicio si es llamado, para explicar y aclarar las conclusiones que haya podido obtener.

También se ha dicho que, si bien no es cien por ciento confiable, ningún instrumento lo es ni puede superar completamente los errores humanos. Sin embargo, según KIRCHER y RASKIN (1988), con la existencia del polígrafo computarizado se ha podido lograr un mayor nivel de confiabilidad, puesto que la computadora obtiene resultados más consistentes y minuciosos, lo cual resulta ser como un segundo examinador que observa las gráficas y las interpreta.

Si bien es imperativo admitir la naturaleza polémica del polígrafo ${ }^{42}$, no lo es menos aceptar las discusiones acerca de medios probatorios como el testimonio, la confesión, el indicio, etc.; incluso algunos expertos en la materia afirman que solo las pruebas del ADN superan en confiabilidad los resultados del polígrafo ${ }^{43}$.

Como ya se indicó, hoy la aplicación válida del polígrafo es reconocida en sesenta y ocho países, entre los cuales dieciséis se encuentran en América Latina ${ }^{44}$. Dentro de los países más desarrollados que lo aplican se destacan Estados Unidos, Canadá, Inglaterra, Holanda, Rusia, Bélgica, Israel, Japón y Austria, en los cuales el "nivel de confiabilidad oscila entre el 80 y el 95\%, estando ligada a la técnica de interrogatorio empleada" 45 .

41 Tapias, Avendaño, Fuentes y Zaldúa. Ob. cit.

42 Muy significativa la conversión de un escéptico en [http://www.elabedul.net/Correos/sobre_el_poligrafo.php].

43 Cfr. [http://www.lafayettecolombia.com/index.php?option=com_content\&view=article\&id=4\&Ite $\operatorname{mid}=6]$.

44 Tapias, Avendaño, Fuentes y Zaldúa. Ob. cit.

45 Cfr. [http://es.wikipedia.org/wiki/Detector_de_mentiras]. 
Bajo tal perspectiva, bien podría considerarse que la naturaleza del polígrafo es la de prueba novel, y bajo tal modalidad podría ser incorporada al juicio oral en el sistema penal acusatorio, utilizando para el efecto, como testigo de acreditación, el interrogatorio del técnico poligrafista, quien explicará la base de la opinión pericial que aparece en la interpretación del examen.

\section{EL POLÍGRAFO Y SU ESTIMACIÓN COMO PRUEBA EN LA LEY ESTATUTARIA DE INTELIGENCIA Y CONTRAINTELIGENCIA (LEY 1621 DE 2013)}

La normatividad legal colombiana ha abordado el tema del Polígrafo y le ha dado su sanción jurídica de admisibilidad, aun cuando en temas muy específicos; empero, tratándose de una Ley Estatutaria, es claro que al ocuparse y referirse al literal a del artículo 152 de la Carta Política, amén del respaldo de constitucionalidad que le dio la Corte Constitucional en su Sentencia C-540 de 2012, no puede afirmarse que dicho instrumento sea contrario a los derechos fundamentales.

\section{A. La Ley de Inteligencia y Contrainteligencia}

La citada Ley Estatutaria disciplina, entre otros aspectos, lo atinente a los principios, fines, límites, mecanismos de control y supervisión, cooperación y coordinación interinstitucional, de las funciones de inteligencia y contrainteligencia del Estado.

La función de inteligencia y contrainteligencia es definida en esta normativa como aquella que desarrollan los organismos especializados del Estado del orden nacional, utilizando medios humanos o técnicos para la recolección, procesamiento, análisis y difusión de información, con el objetivo de proteger los derechos humanos, prevenir y combatir amenazas internas o externas contra la vigencia del régimen democrático, el régimen constitucional y legal, la seguridad y la defensa nacional.

De acuerdo con la ley, tal competencia sólo puede ser ejercida por las Fuerzas Militares y la Policía Nacional organizadas para tal fin, por la Unidad de Información y Análisis Financiero -UIAF-y por los demás organismos que faculte para ello la Ley.

En punto de los límites y fines, dispone que la función de inteligencia y contrainteligencia esté limitada en su ejercicio por el respeto de los derechos humanos y ceñida al cumplimiento estricto de la Constitución, la ley, el Derecho Internacional Humanitario y el Derecho Internacional de los Derechos Humanos. En especial, la función de inteligencia está limitada por el principio de reserva legal que garantiza la protección de los derechos a la honra, al buen nombre, a la intimidad personal y familiar, y al debido proceso. 
En cuanto a los principios que rigen la actividad, indica la referida ley que quienes autoricen y lleven a cabo actividades de inteligencia y contrainteligencia, además de verificar la relación entre la actividad y los fines normativamente enunciados, evaluarán y observarán de manera estricta, y en todo momento, los principios de necesidad, idoneidad y proporcionalidad.

\section{B. Referencias al polígrafo como prueba de admisión y retiro}

El artículo 38 del mencionado cuerpo normativo hace referencia al compromiso de reserva, en los siguientes términos:

[...] Los servidores públicos de los organismos que desarrollen actividades de inteligencia y contrainteligencia, los funcionarios que adelanten actividades de control, supervisión y revisión de documentos o bases de datos de inteligencia y contrainteligencia, y los receptores de productos de inteligencia, se encuentran obligados a suscribir acta de compromiso de reserva en relación con la información de que tengan conocimiento. Quienes indebidamente divulguen, entreguen, filtren, comercialicen, empleen o permitan que alguien emplee la información o documentos reservados, incurrirán en causal de mala conducta, sin perjuicio de las acciones penales a que haya lugar.

Para garantizar la reserva, los organismos de inteligencia y contrainteligencia podrán aplicar todas las pruebas técnicas, con la periodicidad que consideren conveniente, para la verificación de las calidades y el cumplimiento de los más altos estándares en materia de seguridad por parte de los servidores públicos que llevan a cabo actividades de inteligencia y contrainteligencia.

Parágrafo 1o. El deber de reserva de los servidores públicos de los organismos que desarrollen actividades de inteligencia y contrainteligencia, y de receptores antes mencionados, permanecerá aún después del cese de sus funciones o retiro de la institución hasta el término máximo que establece la presente ley.

Parágrafo 2o. Los organismos que desarrollan actividades de inteligencia y contrainteligencia deberán tomar todas las medidas necesarias para impedir que sus miembros copien, porten, reproduzcan, almacenen, manipulen o divulguen cualquier tipo de información de inteligencia o contrainteligencia con fines distintos al cumplimiento de su misión.

Parágrafo 3o. Las personas capacitadas para cumplir funciones relacionadas con las actividades de inteligencia y contrainteligencia, deberán cumplir en todo momento los más altos estándares de idoneidad y confianza que permitan mantener el compromiso de reserva en el desarrollo de sus funciones. Para tal efecto cada una de las entidades que realizan actividades de inteligencia y contrainteligencia, desarrollarán protocolos internos para el proceso de 
selección, contratación, incorporación y capacitación del personal de inteligencia y contrainteligencia, teniendo en cuenta la doctrina, funciones y especialidades de cada una de las entidades.

Parágrafo 4o. La no superación de las pruebas de credibilidad y confiabilidad será causal de no ingreso o retiro del organismo de inteligencia y contrainteligencia de acuerdo con la reglamentación establecida por el Gobierno Nacional. En los organismos de inteligencia y contrainteligencia que no pertenezcan al sector defensa, el retiro del servicio de los servidores públicos que llevan a cabo actividades de inteligencia y contrainteligencia se producirá cuando el nominador, previo concepto de un comité asesor o quien haga sus veces, en ejercicio de la facultad discrecional considere que no se cumple con los estándares de idoneidad y confianza.

Para los organismos de inteligencia y contrainteligencia que pertenecen al sector defensa, el retiro de servicios se hará de conformidad con las normas de carrera correspondientes (cursiva fuera de texto).

Por su parte, el Decreto 857 del 2 de mayo de 2014, por el cual el Presidente de la República reglamentó la Ley 1621 de 2013, aborda en el artículo 20 la regulación de los estudios de credibilidad y confiabilidad, e ingreso y retiro de personal de los organismos de inteligencia y contrainteligencia, así:

Artículo 20. Estudios de credibilidad y confiabilidad. Los estudios de credibilidad y confiabilidad, son de obligatorio acatamiento y comprenden un conjunto de actividades, exámenes y/o evaluaciones, orientadas a asegurar los más altos estándares en materia de seguridad y reserva de la información, mediante la aplicación de exámenes técnicos o evaluaciones periódicas que verifiquen la idoneidad, credibilidad y confiabilidad de los servidores públicos y/o contratistas de los organismos de inteligencia y contrainteligencia y/o de personas que por razón de sus funciones y actividades tengan que conocer información con nivel de clasificación.

En este sentido, los estudios de credibilidad y confiabilidad podrán componerse, entre otros similares, de los siguientes exámenes técnicos que evalúen los siguientes aspectos:

a. Individual: Verificación administrativa de información y datos, referencias, anotaciones, antecedentes judiciales, antecedentes disciplinarios, antecedentes médicos, prueba y evaluación psicotécnica, entrevistas, competencias, prueba informatizada de integridad y veracidad, examen psicofisiológico de polígrafo.

b. Familiar: Visita domiciliaria y de vecindario. 
c. Social: Estudio socioeconómico, referencias personales, profesionales, laborales, comerciales y financieras.

Cada organismo de inteligencia y contrainteligencia determinará el objeto, finalidad y alcance de los estudios de credibilidad y confiabilidad, sus características, ámbito de aplicación, periodicidad, protocolos y procedimientos de realización y evaluación, privilegiando el interés general y la dignidad de los evaluados.

Los organismos de inteligencia y contrainteligencia podrán coordinar su realización con otras dependencias y extenderlos a los procesos y procedimientos internos en cada institución, siempre que tengan relación directa con las actividades de inteligencia, contrainteligencia y los demás fines enunciados en la ley 1621 de 2013.

Parágrafo 1. Los organismos que integran la comunidad de inteligencia, cuando las circunstancias lo requieran, podrán apoyarse entre sí o con organismos homólogos internacionales, para la coordinación y realización de estudios de credibilidad y confiabilidad, con el fin de optimizar las fortalezas institucionales en materia de conocimiento específico, recursos humanos y recursos técnicos especializados.

Para la aplicación de las pruebas de credibilidad y confianza, el nivel de acceso a la información que se haya dado al funcionario y el nivel que posea para la autorización de cada operación o misión de trabajo, cuando fuere el caso, serán factores decisivos para el diseño e implementación del conjunto de exámenes a practicar al funcionario.

Parágrafo 2. Los organismos de inteligencia y contrainteligencia desarrollarán protocolos internos para la aplicación de las pruebas de credibilidad y confiabilidad, cuando se trate de actividades específicas, de apoyo dirigido a la recolección de información a través de fuentes humanas y, de la dirección, orientación y coordinación de equipos especializados de inteligencia, contrainteligencia o asuntos internos, entre otros (cursiva fuera de texto).

Al realizar el control previo de la Ley Estatutaria de Inteligencia y Contrainteligencia, la Corte Constitucional, mediante la Sentencia C-540 de 2012, M. P.: JoRGE IVÁN PALAcio PALACiO, señaló que el artículo 38 del referido cuerpo normativo:

[...] busca salvaguardar la necesaria reserva de la información de inteligencia y contrainteligencia, estableciendo compromisos de reserva y responsabilidades disciplinarias y penales (arts. $1 .^{\circ}, 2 .^{\circ}, 4 .^{\circ}, 6 .^{\circ}, 29,74,209,217$ y 218 superiores). 
El inciso primero instituye que los servidores públicos de los organismos de inteligencia y contrainteligencia, los funcionarios de control, supervisión y revisión de documentos o bases de datos, y los receptores de productos de inteligencia, están obligados a suscribir actas de compromiso de reserva en relación con la información de que tengan conocimiento; lo cual para la Corte no se opone a la Constitución ya que al comprender el manejo de información que envuelve caros intereses para el Estado como la seguridad y defensa de la Nación, es comprensible que el legislador se hubiere preocupado por establecer mecanismos que busquen salvaguardar la necesaria reserva en la materia.

El inciso segundo dispone que para garantizar la reserva los organismos de inteligencia y contrainteligencia podrán aplicar todas las pruebas técnicas, con la periodicidad que consideren conveniente, para la verificación de las calidades y el cumplimiento de los más altos estándares en materia de seguridad por parte de los servidores públicos que llevan a cabo tales actividades; lo cual para la Corte se ajusta al ordenamiento constitucional en cuanto busca asegurar el manejo adecuado y la reserva de la información. Al respecto, debe señalarse que los estudios de seguridad deben fundarse en razones neutrales derivadas de hechos objetivos, ciertos, específicos y relevantes, que además habrá de atender una base fáctica idónea y cierta dada a conocer al servidor público.

El parágrafo $3 .^{\circ}$ se declarará constitucional al limitarse a señalar que las personas capacitadas para cumplir funciones relacionadas con las actividades de inteligencia y contrainteligencia, deberán cumplir en todo momento los más altos estándares de idoneidad y confianza que permitan mantener el compromiso de reserva en el desarrollo de sus funciones. Para este efecto se prevé que cada una de las entidades que realicen actividades de inteligencia y contrainteligencia desarrolle protocolos internos para el proceso de selección, contratación, incorporación y capacitación del personal de inteligencia y contrainteligencia, teniendo en cuenta la doctrina, funciones y especialidades de cada una de las entidades. Para la Corte no se contradice la Constitución en la medida en que el desarrollo de los protocolos internos atienda, entre otros, a criterios objetivos y razonables así como al empleo de factores de evaluación compatibles con las finalidades y requerimientos de la ley de inteligencia.

El parágrafo $4 .^{\circ}$ prevé que la no superación de las pruebas de credibilidad y confiabilidad será causal de no ingreso o retiro del organismo de inteligencia y contrainteligencia de acuerdo con la reglamentación que expida el Gobierno. También establece que en los organismos de inteligencia y contrainteligencia que no pertenezcan al sector defensa, el retiro del servicio de los servidores públicos que llevan a cabo tales actividades, se producirá cuando el nominador, previo concepto de un comité asesor o quien haga sus veces, en ejercicio de la facultad discrecional considere que no se cumple con los estándares de 
idoneidad y confianza. Al respecto, la Corte considera que los actos de retiro del servicio deben estar fundados en un procedimiento previo que permita al retirado ser informado y presentar los descargos, además de soportarse en razones objetivas y estar motivados (art. 29 superior) (cursiva fuera de texto).

En el anotado orden de ideas, la Ley Estatutaria de Inteligencia y Contrainteligencia, y su Decreto Reglamentario, establecen y autorizan el uso del polígrafo como uno de los estándares que han de ser aplicados como prueba de confiabilidad y credibilidad para el acceso a la prestación de servicios en organismos de inteligencia del Estado. Adicionalmente, prevé que la no superación de dichas pruebas, incluida la del polígrafo, permitirá negar el acceso al servicio o, incluso, el retiro del mismo, con lo cual, a los resultados del detector de mentiras se le otorga la categoría o rango de prueba de una justa causa de despido.

Lo señalado pone al descubierto que el ordenamiento jurídico nacional le ha otorgado al polígrafo la categoría de prueba o medio de convicción para acreditar hechos jurídicamente relevantes, lo que constituye un argumento de refuerzo que debe conducir necesariamente a su admisibilidad y licitud también en los procesos penales.

\section{CIENCIAS, NEUROCIENCIAS E INSTITUCIONES JURÍDICAS PROBATORIAS}

El tratamiento judicial que en nuestro medio se ha dado al polígrafo ha sido desafortunado, fundado en especulaciones y prejuicios, soslayando su carácter científico y técnico, creando paradojas verdaderamente inaceptables para negar su admisión como afirmar que solo alcanza un grado de efectividad del $85 \%$ en aciertos, lo cual no deja de ser sorprendente si se tiene en cuenta que el testimonio, base sobre la cual descansa en gran medida nuestra justicia, resulta verdaderamente deleznable no sólo desde su concepción científica sino también como práctica social.

El siglo XIX fue el escenario de la disputa entre la filosofía o metafísica y la ciencia, donde esta influyó en aquélla de tal forma que casi la hace desaparecer, pero con unos resultados bien interesantes respecto del nacimiento de la Teoría de la ciencia y la Teoría del conocimiento a cargo de la Filosofía de la ciencia, como preámbulo de entendimiento de las ciencias de la naturaleza y las ciencias del espíritu. Uno de los aspectos más golpeados de la filosofía radica en la tentativa de su reemplazo por la psicología social -“omnem philosophiae progressum in psychologia constitum esse"-, de lo cual surgieron propuestas de ciencias particulares muy importantes, como resultó ser la psicología con rasgos profundamente culturales ${ }^{46}$.

46 Cfr. Klaus Christian KöHnKe. Surgimiento y auge del neokantismo. La filosofía universitaria alemana entre el idealismo y el positivismo, José ANDRÉs ANCONA QuIROZ (trad.), México, Fondo de 
Se produjo un big bang de conocimientos que aunque fue menguando poco a poco, hoy parece revitalizarse y con superlativa fuerza e intensidad, por virtud de la entrada en escena de las neurociencias, las cuales prometen grandes transformaciones en los estudios científicos, y muy especialmente en una nueva perspectiva de entendimiento entre ciencias de la naturaleza y ciencias del espíritu, siendo paradigmática la afirmación de la existencia de nuevas disciplinas como la llamada "neurofilosofía", campo perteneciente a la moderna neurociencia ${ }^{47}$.

Se afirma con propiedad que "la ciencia y la tecnología avanzan a un ritmo nunca visto en la Historia de la Humanidad", y es preciso, para lo cual se cita al gran científico AnTONio DAMASIO, que tal tipo de conocimiento se traslade al público en general, y muy especialmente a los gobernantes ${ }^{48}$, puesto que así se legitiman en la conciencia colectiva los procesos legales y de justicia que demandan la incorporación de los avances científicos pertinentes y relevantes al conocimiento jurídico.

Entrado el siglo XXI los científicos han comenzado a plantear la necesidad de que en el futuro las neurociencias trabajen conjuntamente con otras disciplinas culturales y sociales, de forma que propicien un "diálogo entre las neurociencias y los diferentes dominios de la sociedad" fundado en "trabajos mancomunados e interdisciplinarios". Cumple así la ciencia la "metáfora" contundente y extraordinaria "capaz de formular las preguntas y elaborar las respuestas sobre grandes desafíos" culturales y sociales, pues también a la sociedad le sirve de modelo para su desenvolvimiento, aun en temas que fueron de dominio de filósofos y juristas con claras implicancias éticas, legales y judiciales ${ }^{49}$; y como lo afirma el neurocientífico JEAN-PIERRE CHANGEUX, es necesario hacer "una reflexión crítica que confronte los diversos planteamientos de las ciencias de la vida y las ciencias humanas y sociales acerca del cerebro humano y su función", a partir de una metodología multidisciplinaria ${ }^{50}$.

Dice el sociólogo y antropólogo ROGER BARTRA que la expansión de las neurociencias "contribuye creativamente a borrar las tradicional frontera entre las humanidades y las ciencias naturales" 51 .

Cultura Económica, 2011, pp. 27, 30, 38, 53, 54, 73, 89, 138, 139, 161, 177, 182, 243, 259, 275, y muy especialmente 292.

47 FACUNDO MANES y MATEO NiRo. Usar el cerebro. Conocer nuestra mente para vivir mejor, Bogotá, Editorial Planeta, 2014, p. 267. Muy especialmente Jean-Pierre Changeux. El hombre de verdad, Virginia Aguirre (trad.), México, Fondo de Cultura Económica, 2005, p. 247.

48 Eduardo Punset. El alma está en el cerebro. Radiografía de la máquina de pensar, Barcelona, Ediciones Destino, 2012, pp. 80 y 180.

49 Cfr. Manes y NiRo. Ob. cit., pp. 23, 30, 31, 34, 37, 84 y 85.

50 Changeux. Ob. cit., p. 11. También se reclaman los estudios multidisciplinarios en materia de la mente humana por Jordi Agustí, Enric Bufill y Marina Mosquera. El precio de la inteligencia. La evolución de la mente y sus consecuencias, Barcelona, Crítica, 2012, p. 9.

51 Roger Bartra. Antropología del cerebro. Conciencia, cultura y libre albedrío, México, Fondo de Cultura Económica, 2014, p. 171. 
En efecto, hoy la "neurociencia demuestra que no se trata de que tengamos cerebro, sino de que somos nuestro cerebro" 52 . Las imágenes eléctricas y las ondas electromagnéticas que produce el cerebro pueden ahora ser captadas por novedosas y complejas máquinas, por ejemplo, escáneres cerebrales, a partir de las cuales es posible inferir "el funcionamiento interno del cerebro mientras experimenta sensaciones y emociones", lo cual pone a las neurociencias ante una nueva revolución del conocimiento humano, solo comparable con la generada por la invención del telescopio aplicado a la astronomía ${ }^{53}$.

Con aparatos de tecnología de punta como los Tomógrafos por Emisión de Positrones -PET- y la Resonancia Magnética Funcional-RMF-, por medio de los cuales es posible "observar la actividad cerebral in vivo" y deducir si una persona miente o dice la verdad, se confirma que la metodología usada por el polígrafo es correcta, toda vez que también se funda en la detección de "ciertos estados de ánimo, como la ansiedad o el miedo que vienen asociados con la mentira" ${ }^{54}$.

Algunos científicos que se ocupan del tema afirman que dichas máquinas tienen la capacidad de acertar la mentira o la verdad en las respuestas dadas por quien se somete a ellas con una precisión igual o superior al 95\%. Y desde ya predicen su necesario y útil uso en los procesos legales y de justicia e, incluso, la creación de aparatos futuristas para la lectura del pensamiento y la descarga de los recuerdos que almacena en el cerebro cada persona ${ }^{55}$.

Las neurociencias han puesto de presente algunos fenómenos de la fisiología cerebral que tendrán que repercutir en una redefinición de los institutos jurídicos sempiternamente reconocidos, necesitados de urgente actualización y revisión, pues no resulta tolerable que las prácticas judiciales pretendan fundar verdades jurídicamente relevantes al margen de lo que acreditan los científicos.

Es claro que mediante el uso del polígrafo y de los escáneres cerebrales la persona conserva la facultad de decisión, pues el sometimiento es libre e informado y, si lo considera conveniente, puede poner fin al proceso en cualquier momento, cuestiones estas que en cierta forma no se podrían alcanzar con otros métodos como el del pentotal sódico, droga que "reduce la actividad de la corteza prefrontal, haciendo que una persona se vuelva más relajada, habladora y desinhibida" 56 , muy cuestionado con toda razón, pues el sujeto queda privado del ejercicio de su libertad mientras está bajo sus efectos.

52 Cfr. Punset. Ob. cit., p. 107.

53 Cfr. KaKu. Ob. cit., pp. 23 y 45.

54 Cfr. MANes y NiRo. Ob. cit., pp. 28, 29 y 49.

55 Cfr. KAKU. Ob. cit., pp. 48 y ss., especialmente pp. 116 y ss., y 148 y ss.

56 Cfr. ibíd., pp. 248 y ss. 
Si tal es el conocimiento sólido y certero a que han llegado las neurociencias, nos preguntamos cuál es la razón para que otros medios probatorios que verdaderamente sí resultan cuestionables en grado sumo tengan todavía tan numerosos adeptos, lo cual parece más asunto de fe que de ciencia.

Con respecto al testimonio, cualquiera que se aproxime al tema se preguntará inmediatamente como el mismo tiene tan amplia aceptación y no así el polígrafo, cuando este tiene claros y evidentes soportes científicos, y aquél solo cuestionamientos que lo horadan cada vez más en cuanto a su idoneidad en la producción de credibilidad judicial.

La misma neurociencia que acredita el polígrafo, rechazado por la práctica judicial no por vía de razonamientos jurídicos sino técnicos, desacredita el testimonio, validado por la justicia por razones inconfesables de mala práctica judicial, pero tambaleante desde perspectivas científicas modernas.

Muy a pesar de ello, la justicia, de espaldas al mundo científico, por efecto del poder desnudo, y ausente de la fuerza que otorga la razón, sigue despreciando lo útil y refrendando lo maculado.

Quien de alguna manera se aproxime al tema seguramente se preguntará por qué resulta tan escabroso tal estado de cosas si, científicamente, se encuentra acreditado que:

1. El sujeto que percibe extracta apenas un $10 \%$ de la representación de la realidad externa que se forma en su cerebro, por lo que "nuestra percepción del mundo es muy sesgada", toda vez que "la mayor parte de lo que vemos lo construye el cerebro" 57 , pues el $90 \%$ restante hace parte de la interpretación que el más complejo órgano humano ha condicionado evolutivamente a partir de procesos inconscientes, intuitivos, de sentido común y experienciales.

En ese sentido los científicos afirman que

La actividad cerebral que crea una percepción del mundo visual al traducir patrones de luz y colores en objetos y eventos es, quizá, uno de los actos creativos más sofisticados. Por eso, más que del cristal, todo parece depender del cerebro que interpreta lo que se mira [esto es] el cerebro visual no retrata la realidad como una máquina de fotos sino que le otorga un significado a las imágenes (tanto en forma consciente como no consciente). El ojo captura

57 El neurocientífico MARCUS RAICHLE, luego de serias investigaciones, afirma que "el 10 por ciento de las sinapsis de nuestro sistema visual procede de lo que vemos, el resto lo construye nuestro cerebro", esto es, "poseemos nuestras propias gafas para ver el mundo y esto determina nuestras creencias"; citado por Rosa CASAFONT. Viaje a tu cerebro, Barcelona, Ediciones B, 2014, pp. 67, 178, 286 y 287. 
información incompleta del mundo externo a partir de una imagen que no es $100 \%$ fidedigna: retiene lo más importante y descarta los detalles más triviales. El cerebro es, en realidad, el órgano que le da sentido a esta información ${ }^{58}$.

Pues bien, si ello es así, ¿dónde radica la tan amplia aceptación del testimonio como prueba sí, en gran medida, lo representado en el cerebro no coincide con la realidad externa como suceso histórico? Sólo un acto de fe, por supuesto con total ausencia del método científico, puede sostener hoy las tendencias judiciales que subliman la certeza del testimonio.

2. Es cierto que la percepción de los hechos es importante, uno de los temas favoritos de la crítica judicial del testimonio, empero, son aún más importantes los llamados tres estadios que hacen parte de la capacidad de recordar, a saber, "codificación, almacenamiento y recuperación" 59 , toda vez que en los mismos se presentan situaciones hoy desveladas por la ciencia, que de alguna manera ponen de presente que, muy a pesar de la sinceridad de un testigo que relata su conocimiento histórico, al mismo han penetrado elementos que no hacen parte de la fidelidad de lo ocurrido.

Esto es, en medio de los fenómenos de incorporar la información y registrarla, que se corresponde con la codificación, de guardar la información en la memoria hasta tanto se necesite, aspecto atinente al almacenamiento, y recobrar el recuerdo cuando se necesite, lo que toca con la recuperación, pueden haberse incorporado elementos extraños a los sucesos acaecidos en el momento de la percepción.

En efecto, el testimonio como prueba judicial es la expresión de la llamada "memoria autobiográfica" o "episódica", la cual apunta a la "colección de los recuerdos de nuestra historia" en términos de espacio y tiempo; sin embargo, debe precisarse, como lo ha demostrado la neurociencia, que "la forma en que recordamos un evento en particular no es muchas veces una recopilación exacta de cómo sucedió originalmente, sino el modo en que lo relatamos la última vez" 60 ; es decir, los "recuerdos pueden ser modificados -revisados-intencionalmente por la incorporación deliberada de nueva información que traiciona la verdad" 61 .

Se ha demostrado que "la memoria, cuando se evoca, se hace inestable, frágil y permeable a nuestras emociones del presente", dado que, como señalan científicos altamente reconocidos, "nuestro cerebro puede cambiarse a sí mismo":

58 Cfr. MANES y NiRo. Ob. cit., pp. 76 y 78.

59 Cfr. ibíd., p. 126.

60 Cfr. ibíd., pp. 137 y 138.

61 Changeux. Ob. cit., p. 113. 
Cuando uno tiene un recuerdo almacenado en su cerebro y se expone a un estímulo que se relaciona con aquel evento, va a reactivar el recuerdo y a volverlo inestable nuevamente por un período corto de tiempo, para volver a guardarlo luego y fijarlo nuevamente en un proceso llamado reconsolidación de la memoria. La evidencia científica indica que cada vez que recuperemos una memoria de un hecho, esta se hace inestable permitiendo la incorporación de nueva información. Cuando almacenamos nuevamente esta memoria, como una nueva memoria, contiene información adicional al evento original. En otras palabras, muchas veces aquello que nosotros recordamos no es el acontecimiento exactamente cuál fue en realidad, sino la forma en que fue recordado la última vez que lo trajimos a la memoria ${ }^{62}$ (cursiva fuera de texto).

\section{Dice Changeux}

... cada vez que realizamos una evocación de nuestra memoria, hacemos una modificación o reconstrucción de la vivencia pasada, incorporando en ella las experiencias nuevas experimentadas posteriormente a la misma. Por este motivo podemos comprobar en ocasiones que recordamos sucesos de forma diferente a como los recuerdan otras personas que vivieron nuestra misma experiencia $^{63}[\ldots]$ a veces, lo que parece verdad para alguien no lo es a los ojos de otro, lo cual ocurre en plena conciencia.

Además, afirma:

El hecho de que haya una intrusión de inexactitudes o distorsiones en la rememoración indica que los recuerdos no consisten simplemente en rememoraciones directas de las cosas, sino que serían más bien el resultado de test internos referidos a hipótesis ${ }^{64}$.

Súmase a ello que nuestro hemisferio cerebral izquierdo hace las veces de "intérprete", con lo cual

... toma la información que tiene (percepciones, memorias, acciones y la relación entre ellas) e inventa un relato coherente para nuestra conciencia, armando así una narrativa personal. Es decir que nuestra narrativa personal está basada tanto en memorias verdaderas como en aquellas memorias falsas, que son el resultado de la interpretación del hemisferio izquierdo sobre los datos que le llegan ${ }^{65}$.

62 Cfr. Manes y Niro. Ob. cit., pp. 138, 152 y 156.

63 Cfr. Casafont. Ob. cit., pp. 102 y 265.

64 Changeux. Ob. cit., pp. 79 y 113.

65 Cfr. Manes y Niro. Ob. cit., pp. 68; también Agustí. Ob. cit., p. 111. 
Qué parte de lo afirmado por un testigo sincero pertenece a su construcción subjetiva y personal, y qué a lo realmente ocurrido en un espacio y tiempo determinado.

Científicos como PASCUAL-LeOne, tomando también los conocimientos aportados por el colombiano RodOLFO LlinÁs, afirman que "el hombre cree que tiene que ver para creer, y el cerebro tiene que crear para poder ver". Algunos psicólogos como Michael GazZAniga llaman a esta destreza "cerebro intérprete"; en fin, dice MoRGADO BERNAL que "el cerebro crea la mente y nos hace percibir lo que ocurre fuera y dentro de nuestro cuerpo de un modo especial y fascinante que no tiene por qué coincidir con la realidad misma" 66 , de allí que, "de él depende en primera instancia toda la cognición humana" 67 .

Tales afirmaciones provienen no solo de los neurocientíficos, sino que también los expertos en biología evolutiva opinan lo mismo, por ejemplo, RICHARD DAWKINS estima que "nuestros sentidos se engañan fácilmente", de allí que "la fe ingenua en nuestros sentidos no es una guía infalible para hallar la verdad"68.

Nótese que hablamos aquí del testigo sincero, piénsese pues cómo expurgar lo realmente percibido de lo creado por aquel interesado y/o mendaz, y sobre todo cuál es la información adicional que no pertenece al evento original y que ha sido incorporada a través de múltiples evocaciones, muy especialmente cuando las mismas sufren el trauma de la disparatada información mediática.

1) Dice la ciencia que "las emociones son las que nos hacen, sin más, seres humanos", desatando cambios fisiológicos y comportamentales relevantes. Las emociones son, también, sin más, pasiones como las llamaban los filósofos griegos, por tanto piénsese cómo valorar la conducta humana si científicamente se encuentra acreditado que "decidimos, básicamente, con las emociones"69.

Las emociones influyen en nuestro comportamiento y decisiones de tan significativa manera que pueden dar origen a lo que se conoce como "desviación sesgada", fenómeno psicológico según el cual apartamos datos desfavorables a nuestros intereses y sólo tendemos a tener en cuenta los favorables, por eso coloquialmente se dice que vemos sólo lo que queremos ver ${ }^{70}$.

66 Cfr. Casafont. Ob. cit., pp. 11, 109 y 178.

67 Agustí et al. Ob. cit., p. 62.

68 Cfr. RichaRd DawKins. El capellán del diablo. Reflexiones sobre la esperanza, la mentira, la ciencia y el amor, RAFAEL GONZÁLEZ DEL SolAR (trad.), Barcelona, Editorial Gedisa, 2008, pp. 28 y 29. Con una muy buena explicación CANGEAUX. Ob. cit., pp. 244 y ss.

69 Cfr. MANes y NiRo. Ob. cit., pp. 189, 191, 192 y 231. Para más detalle en cuanto a la forma en que inciden las emociones en nuestro comportamiento cfr. CASAFONT. Ob. cit., pp. 215 y ss.

70 Cfr. PUnSET. Ob. cit., pp. 192, 271 y 308. 
2) Científicos de renombre mundial como DAwkins ponen de presente los peligros de los llamados "virus mentales" soportados en la fe, lo cual puede tener serias repercusiones en el comportamiento humano, en tanto crean "ambientes favorables para las ideas o para la información autorreplicadora parasítica”, incluso difíciles de detectar para sus propias víctimas ${ }^{71}$.

Los lavados de cerebro son una realidad científica, y según criterio de los expertos en la materia,

... si hay muchas personas que constantemente te dicen lo mismo y no hay nadie que te ofrezca algo distinto, la realidad se convertirá para ti en lo que esa gente te diga. No hay nada más, no hay opciones, no hay fuentes alternativas de información ${ }^{72}$.

Piénsese pues, en el testimonio de personas bajo el influjo de dichos procesos de intervención psicológica, las cuales aun siendo sinceros, no dicen la verdad.

3) Tampoco se puede dejar de lado lo que la ciencia hoy tiene acreditado:

A lo largo de nuestra vida, el cerebro va creando un marco psicológico del que es muy difícil salir, como si desde pequeños nos hubieran puesto unas gafas que se interpusieran entre el pensamiento y la observación de la realidad ${ }^{73}$.

Emociones y pasiones ${ }^{74}$, sin afirmar que ello sea absolutamente determinante en todos los casos, toda vez que "no son un lujo" y "son absolutamente imprescindibles" para entender nuestro comportamiento ${ }^{75}$, pueden influir consciente e inconscientemente en el testimonio como revelación de un pretendido hecho histórico.

Nuevamente nos preguntamos: ¿por qué en la búsqueda de la verdad es judicialmente válido e idóneo el testimonio y no así el polígrafo? La metáfora científica, que como se vio sirve de pauta para otras disciplinas culturales y sociales tan estrechamente ligadas ontológicamente, no deja sentir a cabalidad, en este sector del conocimiento, todas sus consecuencias y repercusiones.

Si frente al polígrafo la ciencia ofrece conocimientos relevantes para su acreditación técnica, y por supuesto jurídica, ¿seguirá siendo válido el parroquialismo gnoseológi-

71 DAwKins. Ob. cit., pp. 188 y ss.

72 Cfr. Punset. Ob. cit., pp. 132 y ss.

73 Cfr. ibíd., p. 123.

74 Cfr. Antonio Damasio. El error de Descartes. La emoción, la razón y el cerebro humano, JoAN Domenec Ros (trad.), Barcelona, Ediciones Destino, 2013, pp. 185 y ss.

75 Cfr. KaKU. Ob. cit., pp. 302 y ss. 
co que padecemos frente al tema, cuando la misma ciencia dice que "ser inteligente es tener flexibilidad para mirar un problema y ver ahí una posibilidad nueva, una salida antes no pensada para enfrentarlo"76? Es necesario, en consecuencia, "derribar las fronteras entre campos de conocimiento" 77 y comenzar a sintonizar los asuntos legales y de justicia con los conocimientos que aporta la ciencia.

Ante descubrimientos certeros los científicos claman porque se aborden los temas legales y de justicia a partir de los conocimientos ofrecidos por la ciencia, poniendo de presente los graves errores que actualmente se cometen, como, por ejemplo, en la organización del llamado juicio por jurados, que va en contra de todo lo que enseñan los principios del muestreo estadístico y el diseño experimental ${ }^{78}$.

La jurisprudencia americana ha sabido superar los retos que ofrecen la modernidad y los avances tecnológicos propiciados por la ciencia, cumpliendo con el paradigma que la caracteriza según el cual los cambios no se producen pensando en el hoy ni en el mañana, sino en el pasado mañana, muestra irrefutable de coherencia y solidez que pone a resguardo de parásitos dañinos como el azar y la coyuntura la ciencia jurídica, pues no sólo ha admitido como prueba de investigación el polígrafo, sino otras de carácter científico como la hipnosis, lo cual muestra hasta qué punto el enfoque asumido en este trabajo puede resultar productivo para la evolución y aceptación de la temática trabajada.

Científicamente ha quedado demostrado que "durante la hipnosis el sujeto tiene una estimulación sensorial mínima procedente del exterior", lo cual le permite "acceder a algunos recuerdos que están enterrados", sin cambiar su personalidad ${ }^{79}$, lo que garantiza igualmente la voluntad libre, consciente e informada que preludia la legitimación de la intervención, presente no sólo en pruebas corporales y de fluidos, sino también psicológicas, psiquiátricas y, en general, en todo el ámbito del fenómeno de la imputabilidad. Es más, basta interrogarse sobre cuál es la razón por la que se admiten el allanamiento de cargos y las negociaciones de culpabilidad, y no la voluntad libre, consciente e informada de someterse al polígrafo, si la práctica demuestra fehacientemente que en no pocos casos ello se hace para librarse de un proceso tortuoso, aún siendo inocente, la persona que no quiere correr el albur de un fallo judicial erróneo y se precipita a padecer un mal menor, o mediante su conducta favorece a un ser querido, razón de ser de la existencia de delitos como la "falsa autoacusación" (art. 437 del Código Penal).

\footnotetext{
76 Cfr. Manes y NiRo. Ob. cit., p. 36.

77 Cfr. Punset. Ob. cit., p. 124.

78 Dawkins. Ob. cit., pp. 55 y ss.

79 Cfr. KaKU. Ob. cit., p. 248.
} 
Sobre este tópico de la admisión de la prueba de hipnosis, indica CHIESA APONTE que,

[....] hay una especial preocupación con la persona que se somete a hipnosis para revivir el recuerdo de los hechos sobre los que declarará. Si bien es cierto que el hipnotismo puede revivir percepciones ya olvidadas, también entraña peligros de falsos recuerdos. Como reacción a este problema algunos Estados han aprobado estatutos especiales para condicionar la admisión del testimonio tras hipnosis; algunos estatutos llegan al extremo de prohibir el llamado "hipnotically refreshed testimony". En Rock vs. Arkansas la Corte Suprema de los Estados Unidos se enfrentó a la validez de este tipo de estatuto cuando se utiliza para impedir el testimonio del acusado. A la acusada se le imputó haber dado muerte a su esposo mediante un disparo, aparentemente en medio de una disputa. Como la acusada no podía recordar bien los detalles del incidente, fue sometida en dos ocasiones, por consejo de su abogado, a hipnotismo, llevado a cabo por un experto.

Luego de estos hipnotismos la acusada pudo recordar que el arma se disparó durante la trifulca, sin ella tener el dedo en el gatillo. Con este cuadro, el abogado hizo que un perito examinara el arma y el resultado de la prueba pericial fue que el arma estaba defectuosa y que tendía a dispararse sin que se activara el gatillo, si se caía o tropezaba con algo. El fiscal se opuso al testimonio revivido con hipnosis. El Tribunal lo sostuvo y resolvió que sólo permitiría el testimonio con relación a materia recordada antes de los episodios de hipnosis. El jurado halló a la acusada culpable de homicidio y la Corte Suprema de Arkansas confirmó, rechazando un planteamiento de vicio constitucional en la exclusión del testimonio con la ayuda de la hipnosis. La Corte Suprema de los Estados Unidos revocó al resolver que la regla de Arkansas, prohibiendo el "hipnotically refreshed testimony" violaba el derecho constitucional de la acusada de testificar a su favor.

Este derecho emana de la cláusula del debido proceso de ley, del derecho a la comparecencia compulsatoria de testigos de defensa y de la quinta enmienda, que garantiza al acusado el derecho a elegir entre declarar y no declarar. La restricción a estos derechos que impone la regla de Arkansas es arbitraria y desproporcionada a su propósito. El interés legítimo del Estado en excluir evidencia no confiable no justifica una regla de exclusión per se, al menos en el caso del testimonio de un acusado. La regla de Arkansas excluye tanto el testimonio confiable como el no confiable. En el caso concreto de la acusada, había indicios de confiabilidad, tal como el resultado de la prueba del arma por el perito, que tendía a corroborar lo recordado por la acusada tras la hipnosis. En fin, los Estados pueden condicionar la admisibilidad del testimonio tras hipnosis, y hasta prohibirlo en ciertas circunstancias que indiquen falta 
de confiabilidad, pero sin llegar a extremo de una regla per se, absoluta, de exclusión, al menos en el caso del testimonio de un acusado ${ }^{80}$.

Es esta una enseñanza significativa para la justicia, pues le muestra el camino para no quedar anquilosada, atada a prejuicios sin bases científicas ni tecnológicas, y, por el contrario, recurrir a una interpretación acorde con los derechos fundamentales como aquí la pregonamos, pues nada más absurdo que alegar en abstracto violación a los mencionados derechos cuando en la práctica, al negarse la prueba del polígrafo, se recorta el derecho de defensa de muchas personas que pueden librarse de montajes, encerronas, colusiones procesales y fraudes del mismo carácter que, con otros medios, difícilmente podría convencer a las autoridades de su inocencia. Tales alegatos no son más que saludos a la bandera, justicia formal e insustancial, en términos exactos: metafísica, cuando la realidad camina por otros senderos.

Los derechos fundamentales son mandatos de optimización, y el discurso contra Polígrafo, por fundarse en puros criterios metafísicos, apuesta por mostrar una apariencia de respeto de la libre voluntad, consciente e informada, cuando en el fondo en muchas ocasiones le cierra al procesado la única luz visible en el túnel de la injusticia.

Basta de discursos metafísicos y encubridores de la realidad ${ }^{81}$. Es preciso utilizar la ciencia en beneficio de la justicia, pues pareciera que la orientación actual tuviera más de fedatario y metafísico. Hoy el polígrafo, ante las comprobadas acusaciones falsas y tendenciosas que han obligado a la Fiscalía General de la Nación a crear grupos especiales de investigadores sobre el tema, sería un muy buen instrumento para recuperar cierta credibilidad mínima que se espera de una prueba ampliamente utilizada como el testimonio.

Por demás, también sería un excelente instrumento para orientar las investigaciones y descartar hipótesis, lo que introduciría agilidad, economía, eficacia y eficiencia, traducidos en la tan anhelada celeridad en la justicia.

\section{CONCLUSIONES}

De conformidad con una interpretación acorde con el Orden Público Internacional de los Derechos Humanos, cuya prelación es indiscutible y que se funda en la defensa (arts. 3. ${ }^{\circ}, 124$ y 130 de la Ley 906 de 2004) respetuosa de la dignidad humana (art. 1. ibíd.), y soportados en las ciencias y neurociencias, especialmente en aquellas

80 Ernesto Chiesa Aponte. Tratado de Derecho Probatorio, t. I, Estados Unidos, Publicaciones J.T.S., 2005 , pp. 298 a 299.

81 Sólo las ideas metafísicas puras "no aceptan que las funciones mentales, incluyendo la conciencia, están basadas en la actividad cerebral”: BARTRA. Ob. cit., p. 38. 
facultades de la defensa relacionadas con la identificación de materiales probatorios y la realización de valoraciones que requieran conocimientos técnicos especializados (art. 125 num. 9. ${ }^{\circ}$ ibíd.), podemos afirmar que de la investigación realizada es posible extractar las siguientes fundamentales conclusiones:

1. En general, el polígrafo es un registro de variaciones emocionales (presión arterial, ritmo cardíaco y respiratorio, resistencia eléctrica de la piel, etc.), provocadas por estados de emotividad, que busca detectar reacciones fisiológicas asociadas con el engaño, bajo la premisa de un cuestionario preconcebido, en el propósito de que se delaten signos de mentira. Es por tanto un método auxiliar de investigación que le permite al operador judicial verificar la veracidad de una declaración, con mejores elementos de juicio, es decir, la credibilidad de un testigo o la versión del implicado en hechos con relevancia jurídico penal.

2. En Colombia la normatividad lo admite en el ámbito laboral para efectos de la selección de personal, e incluso como método de investigación de injustos al interior de las organizaciones empresariales, sin que pueda ser utilizada la negativa a someterse al mismo, o el resultado adverso tras su práctica, como motivo válido o justa causa para despedir al empleado, salvo en el evento de pruebas de confiabilidad y seguridad practicadas a los servidores públicos que laboran en organismos de inteligencia estatal, pues, en tal caso, la Ley Estatutaria 1621 de 2013 permite incluso la desvinculación de los empleados que no superen tales pruebas de polígrafo.

3. En el terreno del proceso penal, la jurisprudencia de la Sala Penal de la Corte Suprema de Justicia ha sostenido en reiterada y homogénea línea, y especialmente en la Sentencia del 1. ${ }^{\circ}$ de agosto de 2008, proceso n. ${ }^{\circ} 2647$, que el polígrafo no es admisible como método de averiguación de la verdad, pues se refiere a la credibilidad del interrogado y no a la comprobación de hechos, elementos o circunstancias de la conducta investigada; que

... la prueba de polígrafo se encamina a sustituir al juez en su labor de valoración del testimonio, pues aquél no tiene como finalidad la demostración de un hecho procesal sino la de ofrecer un dictamen acerca de si un sujeto sometido a un interrogatorio dice o no la verdad en las respuestas a las preguntas que se le formulan.

Agrega la Corte que

... antes que consultar las reglas de la sana crítica para argumentar sobre la credibilidad de un testigo, el Juez tendría que dedicarse a determinar otros asuntos, tales como la pericia del examinador, las condiciones en que se realizó y demás aspectos concernientes a sus requerimientos técnicos; y en suma, que encuentra peligros enormes frente a la libertad y a la dignidad del sujeto si se admite la utilización del polígrafo como medio de prueba, pues ese 
dispositivo antes que matizar la tensión entre la finalidad del proceso penal como método de aproximación a la verdad y la de proteger la integridad de los derechos fundamentales comprometidos, contribuye a afianzar más el fin que los medios, debido al dramático proceso de instrumentalización a que se somete a la persona, de quien se extraen mediciones tomadas del monitoreo de las reacciones del sistema nervioso autónomo, para convertir al propio individuo en instrumento de corroboración de una verdad a la que debe llegar la administración de justicia con absoluto respeto por la dignidad humana (cursiva fuera de texto).

Es decir que el polígrafo constituye un procedimiento contrario la dignidad de la persona humana, por cuanto instrumentaliza a la persona que se somete al "detector de mentiras", y despoja al juez de su facultad de valorar las pruebas, y concretamente, el testimonio o la versión del investigado, con apoyo en los principios de la sana crítica, entregando la determinación de los criterios de credibilidad.

4. La doctrina mayoritaria también ha planteado diversas objeciones al uso del polígrafo, relacionadas, por ejemplo, con la relatividad de "la eficacia", porque se basa casi exclusivamente en la pericia del investigador al formular las preguntas en una atmósfera de distensión tal que excluya cualquier estímulo emotivo no ligado con el argumento objetivo del interrogatorio, por lo que una verbalización inadecuada, una modificación en la actitud o cambios bruscos en el tono de voz del examinador al formular las preguntas, o cualquier estímulo externo que interfiera, podrán provocar en un sujeto que no miente reacciones que no podrían distinguirse de las procedentes de la mentira $y$, en un sujeto que miente alterar el grafico en puntos diferentes.

5. Conforme con el artículo 7. ${ }^{\circ}$ del Pacto internacional de Derechos Civiles y Políticos de la ONU (Ley 74 de 1968), "nadie será sometido a torturas ni a penas o tratos crueles, inhumanos o degradantes. En particular, nadie será sometido sin su libre consentimiento a experimentos médicos o científicos" (cursiva fuera de texto). Es claro que dicho texto, de manera categórica, erige al consentimiento libre o consentimiento informado como el presupuesto esencial para la práctica de experimentos o intervenciones corporales, con diversos fines, incluido el polígrafo.

El polígrafo es en esencia un experimento científico encaminado a establecer y evaluar unas reacciones corporales que se producen en circunstancias de tensión ocasionadas por las afirmaciones contrarias a la realidad, y en tal sentido, es el consentimiento libre y consciente de quien se va a someter al mismo, el que valida y otorga licitud a tal método, como bien lo señala el Pacto Internacional de Derechos Civiles y Políticos, sin que sea posible para los jueces colombianos, en virtud del control de convencionalidad, elaborar interpretaciones jurisprudenciales que desconozcan o ignoren el citado estándar. 
6. Si el sometimiento a la prueba técnica es consciente, voluntario e informado, no puede hablarse del quebrantamiento de la dignidad humana como fundamento del orden jurídico (art. 1. ${ }^{\circ}$ de la Carta Política), y mucho menos puede encontrarse allí una instrumentalización del ser humano, pues no se entiende cómo en el proceso penal pueda renunciarse a la prueba, allanarse a cargos, etc., como expresión de la legítima voluntad personal de participar en las decisiones que afectan a los ciudadanos como derecho constitucional fundamental (art. 2 ibíd.), y al mismo tiempo, impedir que el procesado demuestre su inocencia mediante la utilización de la prueba del polígrafo.

7. De la negativa a practicarse el polígrafo no se podrá inferir indicio alguno en contra de la persona, toda vez que, contrario a lo que sucede en el Procedimiento Civil, en el penal y sancionatorio en general no pueden derivarse indicios a partir del comportamiento procesal de las partes.

8. El artículo 237 de la Ley 600 de 2000 consagra el principio de libertad probatoria, lo que significa que el único límite imponible en la materia es el respeto por los derechos fundamentales, el cual es preservado cuando se practica el polígrafo con el consentimiento libre de quien será sometido al examen.

9. El polígrafo es una técnica auxiliar para la averiguación de la verdad, por lo que queda recogida dentro de la teleología de las expresiones "ciencia, arte o técnica" de que da cuenta el artículo 242 de la Ley 600 de 2000. Los asesores especializados ilustran al juez en dichas precisas materias, el cual no se ve suplantado, sino, por el contrario, asesorado en un tópico muy especial y definitivo para la valoración de la prueba. Significa lo anterior, que el técnico poligrafista auxilia o colabora con el juez en un tópico técnico que tiene que ver con criterios para la apreciación del testimonio, los cuales valen también para la exposición del imputado (arts. 277 y 282 de la Ley 600 de 2000).

10. En el terreno de la Ley 906 de 2004, el polígrafo podría eventualmente considerarse una prueba novel, teniendo en cuenta lo establecido en el artículo 422, sobre admisibilidad de publicaciones científicas y aspectos noveles de conocimiento.

11. La Ley Estatutaria de Inteligencia y Contrainteligencia, y su Decreto Reglamentario, establecen y autorizan el uso del polígrafo como uno de los estándares que han de ser aplicados como prueba de confiabilidad y credibilidad para el acceso a la prestación de servicios en organismos de inteligencia del Estado o, incluso, para la desvinculación de empleados. Ello revela que el ordenamiento jurídico nacional le ha otorgado al polígrafo la categoría de prueba o medio de convicción para acreditar hechos jurídicamente relevantes, lo que constituye un argumento de refuerzo que debe conducir necesariamente a su admisibilidad y licitud también en los procesos penales.

12. Con respecto al testimonio, cualquiera que se aproxime al tema se preguntará inmediatamente cómo el mismo tiene tan amplia aceptación y no así el polígrafo, 
cuando este presenta claros y evidentes soportes científicos y aquél solo cuestionamientos que lo horadan cada vez más en torno a su idoneidad en la producción de credibilidad judicial. La misma neurociencia que acredita al polígrafo, rechazado por la práctica judicial no por vía de razonamientos jurídicos sino técnicos, desacredita al testimonio, validado por la justicia por razones inconfesables de mala práctica judicial, pero tambaleante desde perspectivas científicas modernas.

13. El sujeto que percibe únicamente extracta de la realidad externa un $10 \%$ de la representación que se forma en su cerebro, por lo que "nuestra percepción del mundo es muy sesgada", toda vez que "la mayor parte de lo que vemos lo construye el cerebro" ${ }^{82}$, pues el $90 \%$ hace parte de la interpretación que el más complejo órgano humano ha condicionado evolutivamente a partir de procesos inconscientes, intuitivos, de sentido común y experienciales. Si ello es así, ¿dónde radica la tan amplia aceptación del testimonio como prueba si, en gran medida, lo representado en el cerebro no coincide con la realidad externa como suceso histórico? Sólo un acto de fe, por supuesto con total ausencia del método científico, puede sostener hoy las tendencias judiciales que subliman la certeza del testimonio.

14. Cada vez que realizamos una evocación de nuestra memoria, hacemos una modificación o reconstrucción de la vivencia pasada, incorporando en ella las experiencias nuevas experimentadas con posterioridad. Por este motivo podemos comprobar en ocasiones que recordamos sucesos de forma diferente a como los recuerdan otras personas que vivieron nuestra misma experiencia. Que parte de lo afirmado por un testigo sincero pertenece a su construcción subjetiva y personal, y cual a lo que realmente ocurrió en un espacio y tiempo determinado. Y ello, respecto al testigo sincero, piénsese pues de aquel interesado y/o mendaz: ¿cómo expurgar lo realmente percibido de lo creado?, y, sobre todo, ¿cuál es la información adicional que no pertenece al evento original y que ha sido incorporada a través de múltiples evocaciones, muy especialmente cuando las mismas sufren el trauma de la disparatada información mediática?

15. Emociones y pasiones pueden influir consciente e inconscientemente en el testimonio como revelación de un pretendido hecho histórico, y por ello no es plausible que judicialmente sea válido el testimonio como idóneo en la búsqueda de la verdad y no así el polígrafo, pues la metáfora científica, que, como se vio, sirve de pauta para otras disciplinas culturales y sociales, no arroja en este sector del conocimiento, tan estrechamente ligado ontológicamente, el dejar sentir a cabalidad todas sus consecuencias y repercusiones.

82 El neurocientífico MARCUS RAICHLE, luego de serias investigaciones, afirma que "el 10 por ciento de las sinapsis de nuestro sistema visual proceden de lo que vemos, el resto lo construye nuestro cerebro", esto es, "poseemos nuestras propias gafas para ver el mundo y esto determina nuestras creencias": citado por Rosa CASAFOnT. Viaje a tu cerebro, Barcelona, Ediciones B, 2014, pp. 67, 178,286 y 287. 


\section{BIBLIOGRAFÍA}

Alarcón Granobles, HÉctor y Raúl CAdena Lozano. Garantías constitucionales y prueba ilícita, Bogotá, Ediciones Nueva Jurídica, 2004.

Alfonso Rodríguez, Orlando. Prueba ilícita penal, Bogotá, Ediciones Jurídicas Gustavo Ibáñez, 2003.

Bartra, Roger. Antropología del cerebro. Conciencia, cultura y libre albedrío, México, Fondo de Cultura Económica, 2014.

CAFFerata Nores, José I. y Maximiliano Hairabedián. La prueba en el proceso penal, Buenos Aires, Editorial Lexis-Nexis, 2008.

CAPPelleti, Mauro. El proceso civil en el derecho comparado, Buenos Aires, Ediciones Jurídicas Europa América, 1973.

Castillo Ruíz, Diana Milena y Olga lucía Girón Herrera. Viabilidad del Polígrafo como elemento materia de prueba en el sistema penal acusatorio "Ley 906 de 2004”, Bogotá, Universidad Militar Nueva Granada, 2012.

Climent Durán, Carlos. La prueba penal. Doctrina y jurisprudencia, Madrid, Tirant lo Blanch, 1999.

Changeux, Pierre. El hombre de verdad, Virginia Aguirre (trad.), México, Fondo de Cultura Económica, 2005.

Chiesa Aponte, ERnesto L. Tratado de Derecho Probatorio, Estados Unidos de Norte América, Publicaciones JTs, 2005.

DAMASIO, ANTONIO. El error de Descartes. La emoción, la razón y el cerebro humano, JoAndomènec Ros (trad.), Barcelona, Ediciones Destino, 2013.

DAWKINS, RICHARD. El capellán del diablo. Reflexiones sobre la esperanza, la mentira, la ciencia y el amor, RAFAEL GONZÁLEZ DEL SOLAR (trad.), Barcelona, Editorial Gedisa, 2008.

Demetrio Crespo, Eduardo (dir.) y Manuel Maroto Catalayud (coord.). Neurociencias y derecho penal, Buenos Aires, St Gráfico, 2013.

Denti, VitTORIO. Estudios de derecho probatorio, Buenos Aires, Ediciones Jurídicas Europa América, 1974. 
De Urbano Castrillo, Eduardo y Miguel Ángel Torres Morato. La prueba ilícita penal. Estudio jurisprudencial, Madrid, Thomson-Aranzadi, 2007.

FARFÁn Molina, Francisco. La prueba ilícita en el proceso disciplinario, Bogotá, Procuraduría General de la Nación e Instituto de Estudios del Ministerio Público, 2007.

FARFÁn Molina, FRANCISCO. Eutanasia, derechos fundamentales y ley penal, Bogotá, Ediciones Nueva Jurídica, 2008.

FARFÁn Molina, Francisco. Interceptación de comunicaciones telefónicas en el proceso penal y disciplinario, Bogotá, Ediciones Nueva Jurídica, 2014.

Gómez Colomer, JuAn Luis (coord.). Prueba y proceso penal, Valencia, Tirant lo Blanch, 2008.

Gómez Pavajeau, Carlos Arturo. Estudios de Dogmática en el nuevo Código Penal, Bogotá, Ediciones Gustavo Ibáñez, 2003.

Gómez Pavajeau, Carlos Arturo. "Interpretación y aplicación de normas internacionales sobre Derechos Humanos en materia penal y disciplinaria", en Estudios de Derecho Penal y Procesal Penal, Jorge Armando Otálora Gómez, Esiquio Manuel Sánchez Herrera y Manuel Fernando Moya Vargas (coords.), Bogotá, Defensoría del Pueblo, 2013.

Gómez Pavajeau, Carlos Arturo. "Defensoría pública y litigio estratégico institucional”, La Defensa, Revista de la Defensoría Pública, n. ${ }^{\circ}$ 15, Bogotá, Defensoría del Pueblo, 2013.

Gómez Pavajeau, Carlos Arturo y Donaldo Danilo del Villar Delgado. Estándares internacionales vinculantes que rigen la detención preventiva, Bogotá, Defensoría del Pueblo, 2014.

KAKU, MiCHIO. El futuro de nuestra mente. El reto científico para entender, mejorar y fortalecer nuestra mente, JuAn MANUEl IBEAs DELGAdo y MARCOS PÉREZ SÁNCHEZ (trad.), Bogotá, Penguin Random House, 2014.

KÖHNKE, KLAUs CHRISTIAN. Surgimiento y auge del neokantismo. La filosofía universitaria alemana entre el idealismo y el positivismo, JosÉ ANDRÉs ANCONA QUIROZ (trad.), México, Fondo de Cultura Económica, 2011.

LóPez Barja de Quiroga, Jacobo. Instituciones de Derecho Procesal Penal, Madrid, Akal/iure, 1999. 
López Barja de Quiroga, Jacobo. Tratado de Derecho Procesal Penal, Madrid, Thomson-Aranzadi, 2005.

Maier, Julio B. J. Derecho Procesal Penal. Tomo I. Fundamentos. Buenos Aires, Editores del Puerto, 1999.

MANES, FACUNDO y MATEO NiRO. Usar el cerebro. Conocer nuestra mente para vivir mejor, Bogotá, Editorial Planeta, 2014.

Miranda Estrampes, Manuel. El concepto de prueba ilícita y su tratamiento en el proceso penal. Barcelona, Bosch Casa Editorial, 1999.

Moras Mon, Jorge R. La investigación en el proceso penal. La técnica del descubrimiento, Buenos Aires, Abeledo Perrot, 1998.

Parra QuiJano, Jairo. Manual de Derecho Probatorio, Bogotá, Librería Ediciones del Profesional, 2009.

PunSET, EdUARDo. El alma está en el cerebro. Radiografía de la máquina de pensar, Barcelona, Ediciones Destino, 2012.

Romero Pérez, XiOMARA Lorena. Vinculación de las resoluciones judiciales de la Corte Interamericana, Bogotá, Universidad Externado de Colombia, 2011.

Tapias, Ángela; Andrea Avendaño, Ana María Fuentes y Jenny Zaldúa. "Viabilidad de la aplicación en Colombia de las técnicas psicológicas: el polígrafo, el análisis del estrés de la voz, el análisis de contenido basado en criterios, la hipnosis y la entrevista asistida con drogas; para evaluar la credibilidad del testimonio". Disponible en [http://psicologiajuridica.org/psj97.html]. 